\title{
Refugee Claimants and Access to Permanent Housing in the City of Toronto
}

\author{
by \\ Elaha Safi, BA, University of Toronto, 2016 \\ A Major Research Paper \\ presented to Ryerson University \\ In partial fulfillment of the requirements for the degree of \\ Master of Planning \\ in the Program of \\ Urban Development
}




\section{AUTHOR'S DECLARATION}

I hereby declare that I am the sole author of this major research paper. This is a true copy of the MRP, including any required final revisions, as accepted by my examiners.

I authorize Ryerson University to lend this paper to other institutions or individuals for the purpose of scholarly research.

I further authorize Ryerson University to reproduce this MRP by photocopying or by other means, in total or in part, at the request of other institutions or individuals for the purpose of scholarly research.

I understand that my MRP may be electronically available to the public.

Elaha Safi 


\section{ACKNOWLEDGEMENTS}

Firstly, I would like to thank Dr. Magdalena Ugarte for her unparalleled support throughout the past year. Your time, dedication and devotion to helping me throughout the entire process has been invaluable.

Secondly, I would like to thank Dr. Anna Triandafyllidou for recognizing the importance of migration related studies and for providing me with a scholarship that supported my growth as a researcher and a planner.

Thank you to my brothers, Elham and Helal, my in-laws, and my best friends for being a constant source of support and light over the past two years. You have all helped me in ways you'll never know.

Lastly, I would like to thank my best friend and partner Obaid Said, for always being my number one supporter and believing in me no matter what challenge I'm faced with; I would be lost without you. 


\section{Dedication}

For my mom, Zarghona Safi, and all other refugee parents who leave the only place they know to provide better opportunities for their children. Thank you for allowing us to follow our dreams.

We are eternally indebted to you. 


\begin{abstract}
Toronto continues to be a major recipient of refugee claimants and understanding the complexities of their housing trajectories is critical in ensuring they successfully integrate into society. This Major Research Paper (MRP) sets out to expand current understanding about challenges refugee claimants face in their search for permanent housing in the City of Toronto and highlight the coping strategies they have developed to navigate around these barriers. In 2011, a research team led by York University urban social geographer Valerie Preston completed a comprehensive study that compared the housing experiences of different immigrant groups, including refugee claimants, as part of a larger Pan-Canadian study. This study set the foundation for my research, as I followed the same methodological path to determine if Preston's findings still hold value and what new trends have emerged. This paper provides a high-level overview of Toronto's Housing Market and provides background on the current state of refugee housing in the City of Toronto to illustrate the intricacies of the local context. In order to understand the barriers, qualitative research in the form of expert interviews was also conducted with service providers who offer settlement services to refugee claimants. A total of seven interviews were conducted, transcribed and analyzed to identify themes. Interviews with service providers revealed that the most significant barriers were housing market and Affordability, employment, Toronto- specific programs, and systematic gaps. Common coping mechanisms on the other hand, included sharing accommodation and moving beyond the GTHA. Comparisons are made throughout this paper between findings from the Preston study and my research findings.

Keywords: refugee claimants, refugees, Toronto, discrimination, housing affordability.
\end{abstract}


Table of Contents

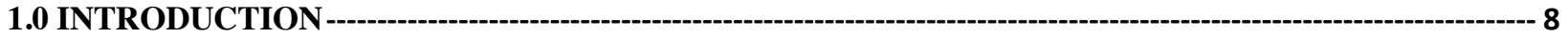

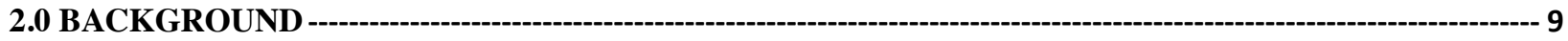

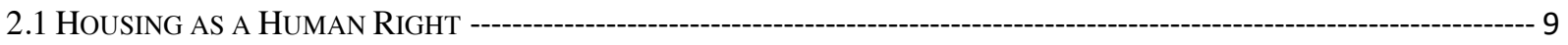

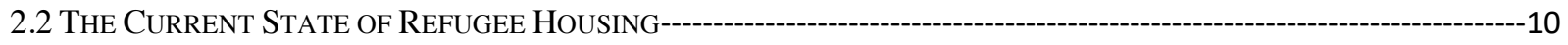

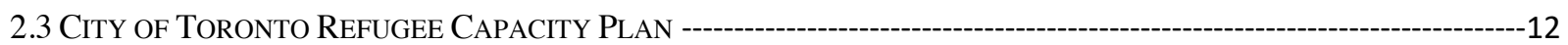

3.0 A REVIEW OF THE LITERATURE ON REFUGEE CLAIMANTS' HOUSING TRAJECTORIES IN

CANADA----

4.0 RESEARCH METHODS -

4.1 RESEARCH FOCUS----_-

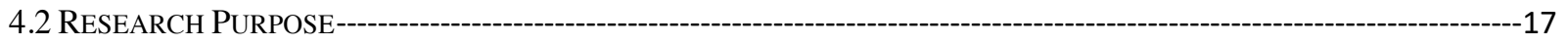

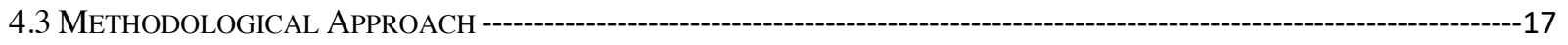

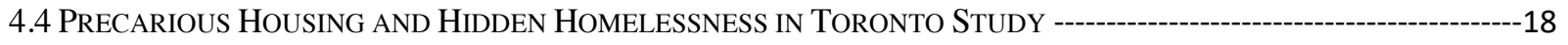

5.0 DATA COLLECTION---

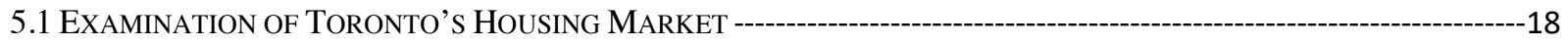

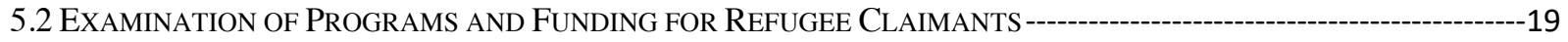

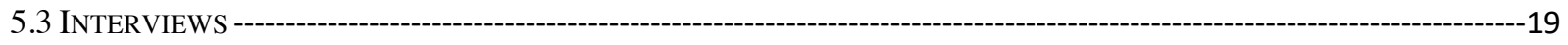

6.0 ANALYSIS ----on

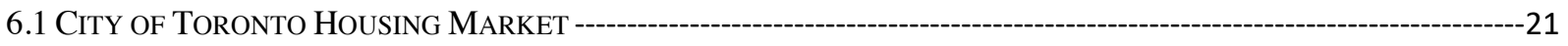

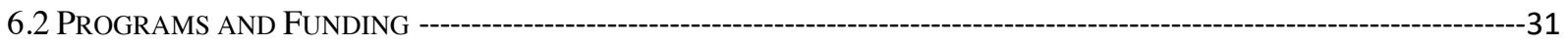

6.3 INTERVIEWS ---

6.3.1 BARRIERS------or

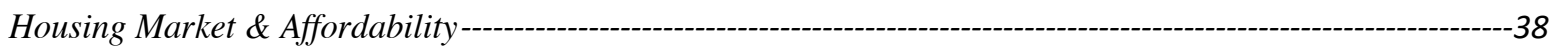

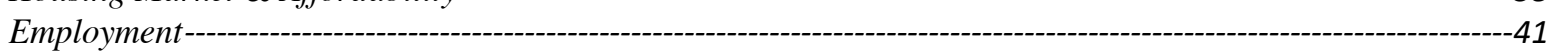

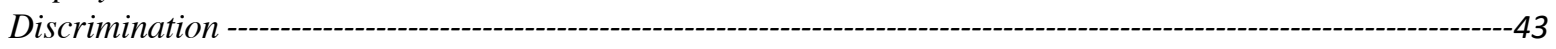

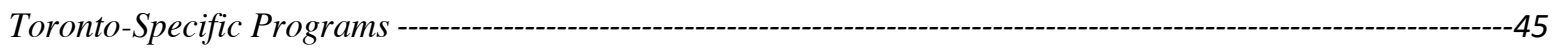

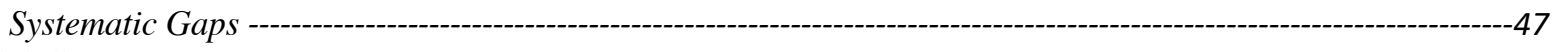

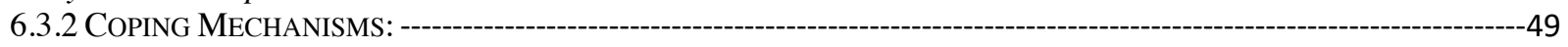

Sharing Accommodation---------------------------------------------------------------------------------------50

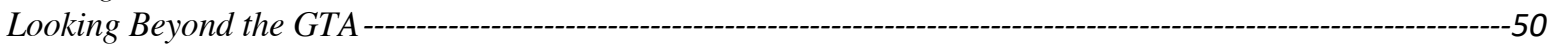

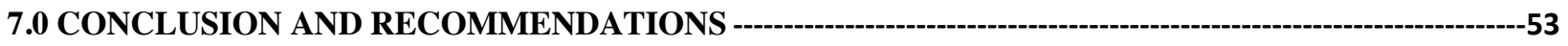

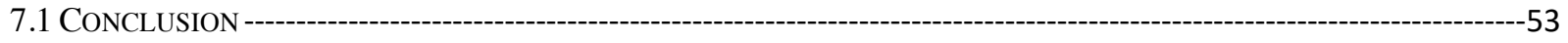

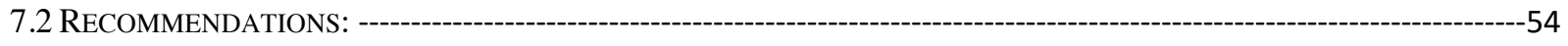

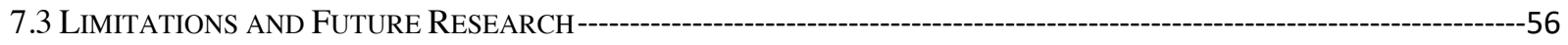

APPENDICES ---

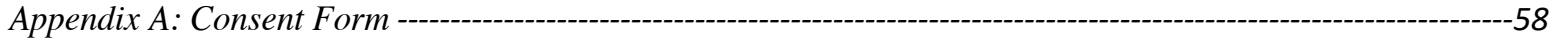

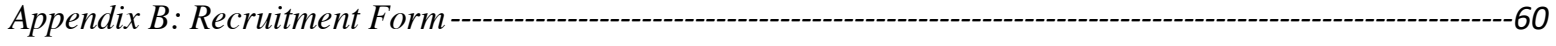

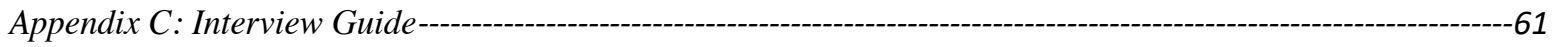




\section{List of Tables}

Table 1 - Total Asylum Claimants Processed by Canadian Border Services Agency and Immigration and Refugee Canada Council Offices January 2013 - December 2019................ 11

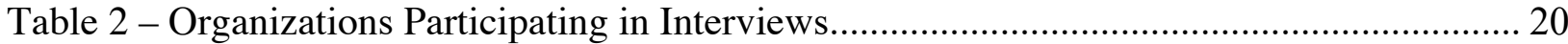

Table 3 - Household Spending ........................................................................................ 27

Table 4 - Increase in Rental Rates from 2010-2019 for 1, 2-and 3-Bedroom Units in Toronto .. 28 Table 5 - Toronto Census Metropolitan Area Average Rents for Rental Condominium

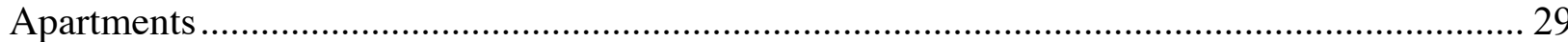

\section{List of Figures}

Figure 1 - Change in Cost of Housing and Household Income ............................................ 22

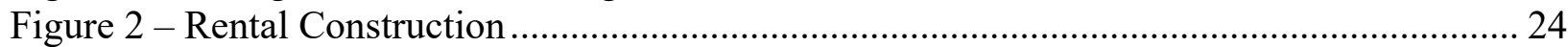

Figure 3 - Vacancy Rates ........................................................................................... 25

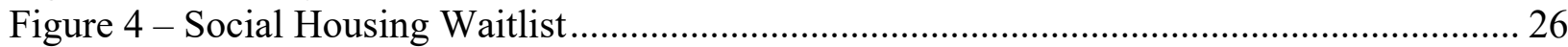

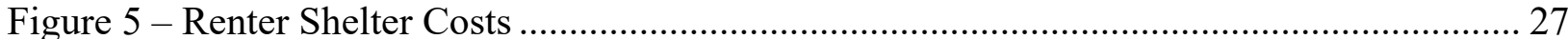

Figure 6 - Average Rent for Bedroom Units ................................................................. 28

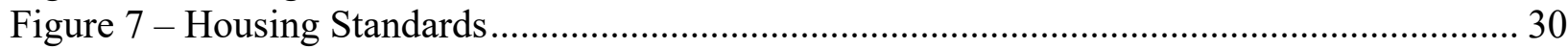




\subsection{Introduction}

Toronto is the main immigrant destination in Canada and continues to be one of the largest recipients of Government Assisted Refugees (GAR's), Privately Sponsored Refugees (PSR's) and refugee claimants (City of Toronto, 2019a). There has been a substantial and sustained increase in arrivals of refugees over the past few decades. In 2013, there were 10,375 refugee claimants in Canada and in 2018 that figure increased to 55,388 (City of Toronto, 2019a). One significant contributing factor is policy changes in the U.S that have made it less hospitable to live there. The Trump administration's decision not to extend a long-standing Temporary Protected Status (TPS) for around 46,000 Haitians was a critical factor in the surge of asylum claimants ${ }^{1}$ in 2017 (Smith, 2019). Additionally, other policies under Trump's administration such as the ban on specific Muslim countries presented Canada as a safe and simple option. For many refugee claimants entering Canada, Toronto was a more desirable destination than many other cities because of the opportunities available in large metropolitan cities (Smith, 2019).

In response to these increases, the City of Toronto has recently adopted a Refugee Capacity Plan (RCP) (City of Toronto, 2019a) to establish an effective approach when dealing with extreme and unplanned service pressures during increased refugee trends. The plan highlights the need to provide refugee claimants with supports that will assist them in transitioning from an emergency shelter, to transitional housing and eventually to permanent housing. In light of this, this MRP seeks to shed more light on the current challenges faced by refugee claimants in obtaining permanent housing. By gaining a deeper understanding of the current challenges, ultimately this MRP will put forth recommendations to improve the refugee claimant's current trajectory of housing.

Canada admits refugees under two major categories: sponsored refugees and refugee claimants. A refugee is a person forced to flee their home country to escape persecution, war or violence (City of Toronto, 2019b). Refugee class is further divided into sponsored refugees (overseas claims) and refugee claimants who come directly to Canada without sponsorship (inland claim).

\footnotetext{
${ }^{1}$ The terms asylum claimant and refugee claimant are used interchangeably.
} 
Sponsored refugees are chosen overseas and come to Canada through government (GovernmentAssisted Refugees) ${ }^{2}$ or private sponsorship (Privately Sponsored Refugees) ${ }^{3}$. Private sponsors can consist of a faith community, place of worship, ethnic association, labour union or a group of individuals. In contrast, refugee claimants ${ }^{4}$ can make a refugee claim once they arrive in Canada, and this can be done at one of Canada's ports of entry such as a land border, airport or seaport. ${ }^{5}$

Refugees are defined and protected in international law. The 1951 Refugee Convention is a key legal document and defines a refugee as "someone who is unable or unwilling to return to their country of origin owing to a well-founded fear of being persecuted for reasons of race, religion, nationality, membership of a particular social group, or political opinion" (UNHCR, Crepeau and Barutciski, 1994). As such, ensuring that they can transition with dignity into their new host society is of utmost importance. In that process, accessing safe and stable housing seems essential.

\subsection{Background}

\subsection{Housing as a Human Right}

The challenge and concern of providing permanent housing for refugees is growing at a steady rate in cities around the world (International Rescue Committee, 2018). The international community has identified that housing is a universal human right that must be protected in law. Through the Universal Declaration of Human Rights in 1948, the United Nations has

\footnotetext{
${ }^{2}$ A person who is outside Canada and has been determined to be a Convention refugee and who receives financial and other support from the Government of Canada or Province of Quebec for up to one year after their arrival in Canada. GARs are selected from applicants referred by the United Nations High Commissioner for Refugees (UNHCR) and other referral organizations (Government of Canada, n.d.)

${ }^{3}$ A person outside Canada who has been determined to be a Convention refugee or member of the Country of Asylum class and who receives financial and other support from a private sponsor for one year after their arrival in Canada. Private sponsors are Sponsorship Agreement Holders (SAHs), Groups of Five or Community Sponsors (Government of Canada, n.d.)

${ }^{4}$ A person who has applied for refugee protection status while in Canada and is waiting for a decision on his/her claim from the Immigration and Refugee Board of Canada (Government of Canada, n.d.)

${ }^{5}$ Refugee claimants can make their claim at the Canada Border Services Agency office when they arrive. If they are already in Canada, they can go to Immigration, Refugees and Citizenship Canada (IRCC) and make an in-land claim (Government of Canada, n.d.)
} 
acknowledged the right to housing in many documents ${ }^{6}$. While the right to housing is not recognized in the Canadian Charter of Rights and Freedoms or the Constitution Act of 1972, Canada has signed on and consented to several international human rights treaties that identify the right to housing (Canada Without Poverty, 2020). However, the Ontario Human Rights Commission outlines housing as a basic human right and suggests that adequate housing is essential to one's sense of dignity, safety inclusion and ability to contribute to the fabric of our neighborhoods and societies (Ontario Human Rights Commission, 2009). Despite this, Toronto, amongst other cities is finding it increasingly difficult to provide affordable, suitable and stable housing to all residents. Some groups are affected more significantly than others by the current affordable housing crisis in Toronto. For instance, residents experiencing homelessness, vulnerable residents and lower-income tenants are faced with high rents, low vacancy rates and high costs of homeownership in Toronto (City of Toronto, 2018). Refugee claimants in particular, are a vulnerable demographic and experience several of these challenges simultaneously.

\subsection{The Current State of Refugee Housing}

As of 2018 there were around 3.1 million asylum seekers in the world, the majority of whom looked to settle in urban areas (IRC, 2018). Cities tend to be more attractive places to settle for refugee claimants because they offer a range of benefits that help refugee claimants integrate successfully into their host society. For instance, cities facilitate personal anonymity, provide connectivity to dense social networks, provide formal and informal labor opportunities and access to essential services that are otherwise difficult to obtain in rural areas (IRC, 2018). Generally, arrivals of immigrants or government-sponsored refugees to Canadian cities are more predictable and less sporadic than refugee claimants, as they are largely based on federal immigration plans. However, the arrivals of refugee claimants are not as predictable and there tend to be more fluctuations, which are a result of economic, social and political unrest in countries around the world (Smith, 2019). As such, there have been significant shifts in the

\footnotetext{
${ }^{6}$ Other international treaties have also affirmed the right to housing including the International Convention on the Elimination of All Forms of Racial Discrimination, the Convention on the Elimination of All Forms of Discrimination Against Women and the Convention of the Rights of the Child. Canada has ratified all of these treaties (OHRC, n.d.).
} 
arrivals of refugee claimants to Canada over the past two decades. In 2008, there were 36,856 refugee claims made in Canada. Five years later that number was 10,375 and in 2018 it was 55,388, as stated earlier (City of Toronto, 2019a). More specifically, when observing the rate of refugee claimants entering Ontario, there has also been a steady increase as displayed in Table 1.

Table 1 - Total Asylum Claimants Processed by Canadian Border Services Agency and Immigration and Refugee Canada Council Offices January 2013 - December 2019

\begin{tabular}{|c|c|c|c|c|c|c|c|}
\hline Year & 2013 & 2014 & 2015 & 2016 & 2017 & 2018 & 2019 \\
\hline Ontario & 6,785 & 9,225 & 11,085 & 16,205 & 20,220 & 22,170 & 26,885 \\
\hline
\end{tabular}

Source: Government of Canada Total Asylum Claims by Year in Ontario 2013-2019

The City of Toronto continues to be a key destination for refugee claimants and asylum seekers, which has had implications on the city's key services (City of Toronto, 2019a). While there have been a wide range of impacts the City of Toronto services, there has been an overwhelming impact on the shelter system. In April of 2018, the City of Toronto's fourth Street Needs Assessment (SNA) provided a glimpse of the city's homeless population. The survey found that at the time, $40 \%$ of those staying in City-administered shelters were refugee/asylum claimants. 6 months later, in October 2019 approximately $36 \%$ of all shelter users in the City's permanent shelter system were refugee claimants, with an average of 18-20 new refugee claimants entering the shelter system each day (City of Toronto, 2019a). The average nightly number of refugee claimants in Toronto's shelter system has increased from an average of 643 per night in November of 2016 to approximately 2,357 in October of 2019 (City of Toronto, 2019b). In turn, Toronto's shelter system has reached saturation, and the city began to house refugee claimants in the city's motel beds program, college dorms and hotels, while many others remain homeless (City of Toronto, 2019a, 2020a). These statistics display how the surge of claimants entering Toronto has overwhelmed the city's shelter service, highlighting the need for a more integrated approach.

The current rate of global urbanization has highlighted the role of cities as safe havens and the dire need for building inclusive communities that respond to the needs of refugees (IRC, 2018). While national governments are critical actors in accommodating the short- and long-term needs 
of refugee claimants, it is often municipalities that fund, design and deliver programs that provide opportunities for social and economic integration (IRC, 2018). Two elements that can foster an inclusive city for refugees are removing obstacles that prevent underserved groups from reaching their full potential and including refugees in long-term city plans and policies (IRC, 2018).

\subsection{City of Toronto Refugee Capacity Plan}

In November of 2017, Toronto City Council recommended a refugee capacity plan be developed because of the irregular increases in arrivals of refugee claimants and the subsequent effects on the city's settlement support services (IRC, 2018). In turn, municipal, provincial and federal government developed this plan in coordination with refugee shelters in Toronto to better respond to the growing needs of this demographic. This plan was developed in part, because the settlement process for refugee claimants was identified as a crucial step in their integration. There was a need for a harmonized effort throughout the city and there were evident policy gaps in connection with obstacles refugee claimants were facing (IRC, 2018). The Refugee Capacity Plan was officially adopted in 2019.

The Refugee Capacity Plan encourages continuous and efficient supply of resources and supports for refugees during situations of extreme and unplanned service pressures. The capacity plan is composed of four main components: management structure, intergovernmental aspects, communications and information management, and community supports. The Refugee Capacity Plan's Advisory Committee have also identified short-term and long-term strategies that will help respond to unexpected surges in the number of refugee claimants entering Toronto.

The strategies include:

1. Creating a 24/7 refugee claimant reception and referral center in order to provide them with timely and relevant service. The intention behind this is to provide a fixed location that refuge claimants can seek help through at any time.

2. Providing more flexibility in the emergency shelter system by extending contracts with hotels that have been transformed to refugee claimant shelters. 
3. Provide additional support for refugee claimants in their search for transitional and permanent housing. One action under this is to conduct an analysis of existing Toronto Community Housing Corporation (TCHC) scattered sites to determine which can be adapted into transitional housing for refugee claimants.

References will be made to the RCP throughout this MRP as it will help to illustrate the dire housing situation of refugee claimants in the City of Toronto, while making connections between challenges refugee claimants face, the proposed interventions of the RCP, and other potential policy changes that could contribute to a more integrated approach regarding housing for refugee claimants.

\subsection{A Review of the Literature on Refugee Claimants' Housing Trajectories in Canada}

Generally, national governments are critical actors in accommodating the short-and long-term needs of refugee claimants, but it is often municipalities that fund, design and deliver programs that provide opportunities for social and economic integration (IRC, 2018). Several Canadian studies have confirmed that refugee claimants experience a more difficult pathway to adequate housing when compared to other immigrant classes like government sponsored refugees and privately sponsored refugees (Murdie, 2008; Hiebert et al., 2009; Preston et al., 2011). This is largely a result of their precarious immigration status and their ability to access the same services as other groups. Difficulties faced by refugees have become more acute since the 90's because the chances of finding adequate and affordable housing have diminished. As I elaborate in Section 6.1 this is a result of cutbacks to social assistance payments from the federal government, lack of new social housing construction, high rents in the private sector and reduced public funding for non-governmental organizations that assist refugees (Murdie, 2008). These challenges are amplified for refugee claimants by limited English proficiency, a lack of recognized human capital and scarce financial resources (Hiebert et al. 2005, Murdie and Texiera, 2001). There have been several studies that have examined access to housing by different immigrant classes in Canada and Toronto. These studies capture the dynamic experiences and housing trajectories of different immigrant groups. Most of these studies incorporate a number of factors that are at play such as household characteristics, individual 
resources (material and cognitive) and preferences, filters in the housing search process, and barriers faced in the housing search as well as coping strategies used to mitigate the barriers (Francis, 2009; Carter, 2010; Cubie, 2006; Hiebert, 2009; Murdie, 2004, 2008, 2010).

Some of the setbacks refugees face in their search for housing include limited language proficiency, limited financial resources and limited knowledge of the customs and strategies used to access housing. In comparison to government sponsored or privately sponsored refugees, refugee claimants have very few local friends or relatives that they can rely on for assistance (Bergeron and Pooter, 2006; Greenberg and Martinez-Reyes, 2010; D’Addario, Hiebert and Sherrel, 2007; Lauer and Yan, 2007). As a result of the above noted factors, sponsored refugees often secure permanent housing much quicker than refugee claimants, and this was validated by Robert Murdie's research in 2008, after interviewing both groups (Murdie, 2008). Sponsored refugees secured permanent housing after one month of being in Canada, while it took refugee claimants approximately seven months to do the same (Murdie, 2008). Other studies indicate that insufficient labor market opportunities hinder the ability of refugee claimants to successfully obtain adequate housing in large metropolitan cities like Toronto, Montreal and Vancouver (Francis, 2009, 2010; Hiebert et al. 2009; Murdie, 2008; Sherell, 2010; Wayland, 2010). Low incomes make it increasingly difficult to find adequate housing and often individuals are obligated to sacrifice other household needs such as food and clothing in order to pay rent. The high cost of private rental housing, long waiting lists for social housing, poor quality housing, overcrowding and discrimination have been highlighted as barriers in several studies that have focused on Toronto and Vancouver. Low employment participation, high housing prices and insufficient social assistance rates were also highlighted as significant barriers in a Winnipeg and Vancouver study (Sherell, 2010).

Murdie (2008) reported that refugee claimants often relied on community agencies, advertisements in local papers and volunteers in shelters when searching for housing. These strategies alleviated barriers such as language and the need for a co-signer on a lease. While some refugee claimants also relied on friends and relatives during their housing search, it proved to be an unfeasible long-term strategy. According to the author, refugee claimants asked for more formal supports because informal supports were not as effective as they would have hoped. For 
instance, supports from family/friends were not as stable because they had other commitments and responsibilities that prevented them from devoting more time in assisting refugee claimants. Other evidence from Vancouver suggests that refugee claimants are often in the most precarious housing situation, characterized by poor housing conditions, crowding and high rent to income ratios. Similarly, Murdie (2008) reports that throughout different Canadian cities, refugee claimants' housing tenure is often linked to their uncertain status. This uncertain status refers to refugee claimants who have submitted claim documents and are awaiting a trial date to confirm whether they can receive permanent residency or if their application has been rejected. In the latter situation, they are given a specific time frame before they have to return back to their initial country of residence.

Other studies conducted also reveal that refugee claimants often experience precarious housing and are at risk of homelessness (Carter and Osborne, 2009; Cubie, 2006; Francis 2010, 2009; Murdie, 2010). Affordability is the most critical housing issue for newcomers in high cost cities like Toronto. Additionally, Preston's study (2011) found that prior to applying for permanent residency status, some refugee claimants experience cycles of hidden homelessness or couch surfing. Refugee claimants are more likely than other immigrants to experience precarious housing or hidden homelessness especially when their economic circumstances decline, or family crises occur. This is because they are often more isolated than other immigrants and have less social capital to rely on in difficult situations such as a job loss or family complications (Preston et al., 2011). This study revealed that more than half of the refugee claimants live in overcrowded and unhealthy housing, and that many were dependent on social assistance, which was also insufficient. Another factor that was highlighted was landlord discrimination, as landlords discriminate on the basis of household size, composition and source of income. The research also found that $1 / 3$ asylum seekers were spending three quarters or more of total household income just on their rent (Preston et al., 2011).

Many refugees and asylum seekers displayed resilience in the face of overwhelming housing difficulties, as they have emphasized their responsibility of adapting to Canadian norms. In their search for help, many often turned to their communities to seek assistance from religious groups and other social organizations and noted that there is a lack of housing information available 
generally. As such, refugee claimants often supported one another with housing help with the knowledge they would obtain through other sources (Preston et al., 2011).

\section{Conclusion}

Through exploring different Canadian studies on the housing trajectory of refugee claimants it is evident that they tend to face similar challenges in their search for adequate housing across provinces and cities. The majority of these studies have focused on challenges and barriers to obtaining permanent housing. The purpose of this MRP is to revalidate barriers that continue to affect refugee claimants' search for housing, determine what new barriers have emerged and how they are navigating them in their search for permanent housing. In particular, this MRP seeks to examine what has changed since Preston's study was conducted, particularly in light of the housing affordability crisis and the recent development of the City of Toronto's Refugee Capacity Plan. This research is important as it can offer the opportunity to reproduce conditions that may be most effective for finding permanent housing. This can help different levels of government or non-profit organizations direct funding to specific types of programs/services that may not be receiving enough funding currently. It might also shed light on the new challenges refugee claimants and service providers face today, compared to ten years ago. However, there are also limitations in this approach because specific scenarios leading to successful trajectories towards finding permanent housing may be difficult to duplicate through policy interventions. This will be expanded on and discussed further in Section 7.

\subsection{Research Methods}

\subsection{Research Focus}

This MRP primarily focuses on refugee claimants. However, throughout the paper some comparisons are made between refugee claimants and GARs/PSRs. These comparisons are often made to illustrate that refugee claimants experience a more difficult housing trajectory. These comparisons have also been highlighted throughout the literature on refugee integration, where many academics have looked at funding and programs available to different refugee classes, and compared their housing trajectories (Carter and Osborne, 2009; Francis 2010; Hiebert, 2009; 
Murdie, 2008). However, this MRP specifically seeks to expand current understanding and add qualitative depth to the literature on refugee claimants in accessing permanent housing in the City of Toronto.

\subsection{Research Purpose}

The primary objective of this research is to examine the challenges faced by refugee claimants in accessing permanent housing in the City of Toronto. These challenges will be discussed from the perspective of service providers in the midst of the housing crisis the city is experiencing. This MRP aims to provide a contemporary snapshot of refugees' housing challenges by building on the comprehensive Preston et al. study completed in 2011. This study will be referenced throughout this MRP, as I explore similarities and differences between its findings and new trends that have emerged over the last decade. This research also ties back to the City of Toronto Refugee Capacity Plan, which was adopted by council in recognition of the growing challenges and needs of refugees who were entering Toronto at high rates. Additionally, there will be a high-level review of how Toronto's housing market has evolved over the past decade, which provides background on the current state of refugee housing in the City of Toronto and illustrates the intricacies of the local context.

\subsection{Methodological Approach}

My research seeks to better understand the challenges refugee claimants face in finding permanent housing in the City of Toronto amidst the housing affordability crisis. It also hopes to uncover coping strategies and success factors through discussion with service providers. In order to do this effectively, three different types of data were collected. The first was an examination of Toronto's housing market, followed by an examination of programs and funding for refugee claimants, and lastly conducting interviews with service providers. Each of these methods allowed me to gain a holistic understanding of the challenges refugee claimants face and situate these experiences in the broader housing affordability crisis Torontonians are experiencing. All three of these data collection methods will be described in further detail in Section 5.0 


\subsection{Precarious Housing and Hidden Homelessness in Toronto Study}

In 2011, a study titled Precarious Housing and Hidden Homelessness Among Refugees, Asylum Seekers, and Immigrants in the Toronto Metropolitan Area was undertaken as part of a panCanadian research project that focused on 3 major gateway cities: Vancouver, Toronto and Montreal (Preston, Murdie, D’Addario, Sibanda, Murnaghan, Logan and Ahn, 2011). This study addressed four main questions and set out to gather more data on the housing circumstance of newcomers to Toronto, key barriers to securing housing for each group of newcomers, strategies used to overcome these barriers and gaps in services that hinder a group's ability to find permanent housing. This study conducted primary research, which involved focus groups with service providers in the city and questionnaire surveys with the newcomer groups. The nature of this research resulted in comparisons between the experiences of all three newcomer groups. This study will be referenced as the "Preston study" from here on.

The Preston study served as the foundation for the development for this MRP, as it was one of more recent studies completed in the City of Toronto with findings that are far-reaching. I was particularly interested in what they did as it incorporated the perspectives of both service providers and newcomer groups. As a result, I decided to follow a similar methodological path to figure out if refugee claimants continue to face the same challenges almost ten years later, if new challenges have emerged and what coping mechanisms have been developed since. My research departs from this and only focuses on refugee claimants.

\subsection{Data Collection}

\subsection{Examination of Toronto’s Housing Market}

To thoroughly understand the surrounding context in which refugee claimants are searching for housing, it was critical to recognize the intricacies and details of Toronto's housing market. To do this, I completed a high-level comparison of Toronto's housing market over the past ten years, with a particular focus on the rental market. There was a more refined focus on the rental market as this is main tenure of housing refugee claimants are in search of during their first few years of settlement. This comparison was done over a 10-year period to understand how the 
market has changed since the Preston study was completed and determine how new housing trends may be exacerbating the challenges refugee claimants face.

Data collection for this portion of the MRP consisted of gathering data tables and information from Canadian Mortgage and Housing Corporation and Toronto-based housing market reports, as well as reading reports on the City of Toronto website. The most relevant and applicable data sets for my research topic were extracted from these sources to illustrate how Toronto's housing landscape has changed, and its subsequent effects on the housing experiences of refugee claimants.

\subsection{Examination of Programs and Funding for Refugee Claimants}

In order to gain a more robust understanding of the types of programs and services refugee claimants in the City of Toronto are eligible for, I conducted an examination of existing programs and funding. This included reviewing rates for Ontario Works, the Resettlement Assistance Plan and examining Toronto specific programs such as the Housing Allowance and the Housing Stabilization Fund. Comparing the following programs and funding available to different categories of newly arrived refugees was an important way to understand how and why the housing trajectories of refugee claimants differ might from those of government sponsored refugees and privately sponsored refugees.

\subsection{Interviews}

Additionally, interviews with service providers served as an integral data collection tool. Initially, primary research in the form of expert interviews and survey questionnaires with settlement service providers and refugee claimants were to be conducted. However, given the timelines of Ryerson's Research Ethics Board and the short timeline for completion of this MRP, the survey questionnaires could not be completed. As a result, the main focus became expert interviews with service providers that provide settlement services to refugee claimants in the City of Toronto.

Information for the interviews was collected through a qualitative approach and was guided by two principles: to understand the challenges refugee claimants experience when trying to access 
permanent housing and to understand the perspectives of service providers that offer settlement services to this demographic. Using a purposive sampling technique, service providers within the City of Toronto were identified and contacted to participate in this study. Outreach involved contacting COSTI Immigration, Romero House, Sojourn House, Matthew House, Afghan Women's Organization, Adam House and FCJ Refugee Centre. Positive responses were received from the organizations identified below, and interviews were conducted with staff members. The purpose of this data collection method was to get a qualitative dive into the perspectives of settlement services workers, and to determine if Preston's findings still hold value, to what extent they hold value, and what new trends have emerged.

Table 2 - Organizations Participating in Interviews

\begin{tabular}{|c|c|c|}
\hline Organization Name & \# of Participants & Positions \\
\hline COSTI Immigration & 5 & $\begin{array}{c}\text { Manager } \\
\text { 4 Housing Workers }\end{array}$ \\
\hline Adam House & 1 & Program Manager \\
\hline $\begin{array}{c}\text { Afghan Women's } \\
\text { Organization (AWO) }\end{array}$ & 1 & $\begin{array}{c}\text { Settlement Program } \\
\text { Manager }\end{array}$ \\
\hline
\end{tabular}

Source: Author

COSTI Immigrant Services is a community-based agency that has been operating since 1952 and provides employment, educational, settlement and social services to all immigrant communities through their 18 locations in the GTA. Adam House is a faith-based organization that also provides shelter for refugee claimants and assists them in finding permanent housing. AWO provides settlement services to all newcomers, with a special focus on women and refugees who have experienced war and persecution. There were no specific selection criteria for the expert interviews other than being a staff member of any of the aforementioned organizations. Expert interviews were conducted with staff at these organizations to understand the type of settlement services they provide, strengths and gaps in service provision, challenges faced as a service provider, and to uncover any success factors in refugee claimant's search for permanent housing.

Service providers were asked to discuss barriers refugee claimants face in their search for permanent housing and the strategies used to overcome these barriers. Six interviews were conducted in person, and one was conducted over the phone. Each interview lasted between 20- 
40 minutes and responses varied based on the specific roles of individuals at the organizations. While the sample of interviewees is small, the purpose of this exercise was not to be representative of all immigrant settlement organizations in Toronto, but rather to get a qualitative dive into the perspectives of on-the-ground practitioners to determine how the housing challenges of refugee claimants have been affected by the affordability crisis and influx of refugees in the city since Preston et al.'s study was conducted. All interviews were digitally audio-recorded and transcribed and analyzed individually. The interviews were analyzed thematically based on emerging themes, as well as paying attention to whether the barriers and coping mechanisms identified in the Preston study - including housing affordability, discrimination, and employment - remained relevant and/or whether other trends became visible.

\subsection{Analysis}

\subsection{City of Toronto Housing Market}

The following section will compare the 2010/2011 housing market, which was when the Preston study was conducted, to the 2016-2020 housing market in Toronto. This comparison will be done with the most up to date data publicly available online. The examination seeks to illustrate the housing affordability crisis the city of Toronto is currently experiencing, and the role of this market in shaping the challenges refugee claimants and service providers are facing. As such, this comparison is not meant to be a comprehensive housing market analysis, but rather a highlevel overview to display how the housing market has evolved over the years.

\section{Home Ownership in Toronto}

From Insight to Action, a recent housing market analysis report recognizes the current housing crisis in the city and provides detailed statistics on the rental and ownership market in Toronto. This report was prepared by the Canadian Centre of Economic Analysis (CANCEA) and the Canadian Urban Institute (CUI) for the Affordable Housing Office (AHO) of the City of Toronto. 
This report provides background information on the growing costs of owning a property in Toronto. It recognizes that owning property in the city of Toronto has become more challenging and expensive (CANCEA and CUI, 2019). For instance, the average cost of owning a home (including condominiums) has increased by $60 \%$ between 2006 and 2018 while the median owner household income declined by 15\% (CANCEA and CUI, 2019). This is displayed in Figure 1. This finding was also echoed by a recent RBC Economics Report (2019a, 2019b). This research revealed that affordability remains at crisis levels in Toronto. The report found that detached homes and condos are both becoming less affordable. Since the ownership market is becoming out of reach for more and more families and individuals, more people are looking to the rental market and this is bringing demand to an all-time high (RBC, 2019a, 2019b).

Figure 1-Change in Cost of Housing and Household Income

\section{Change in Average Cost of Owning a House in Toronto and Median Renter Household Income (before tax), 2006-2018}

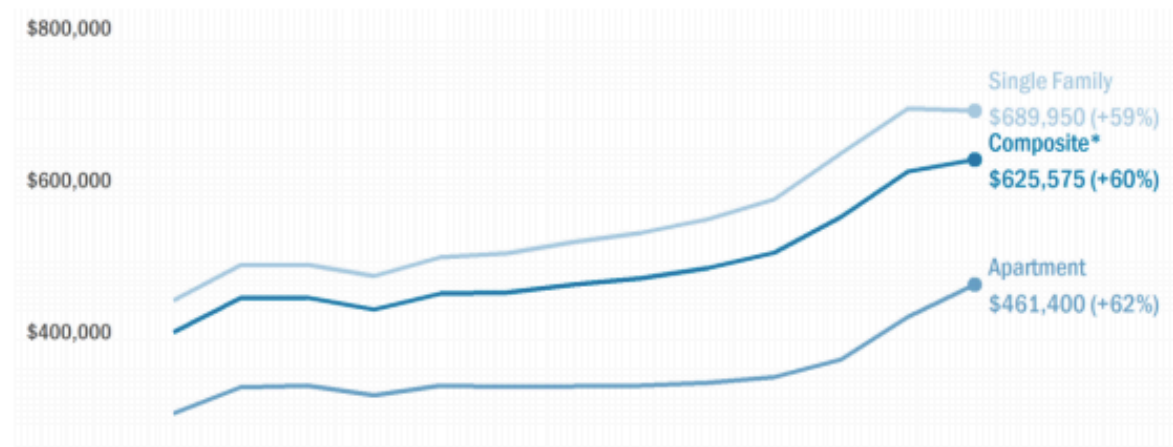

$\$ 200,000$

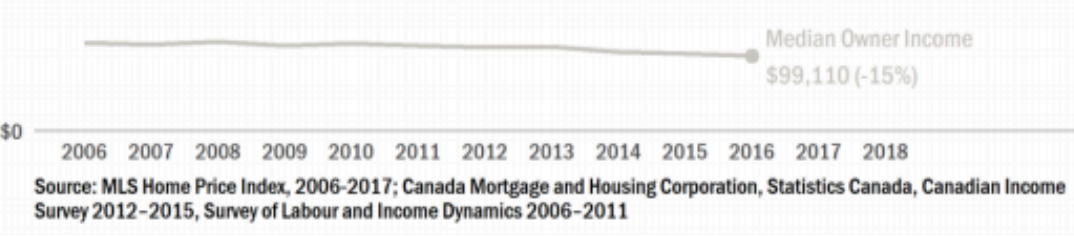

Source: CANCEA and CUI: From Insight to Action (2019).

\section{Toronto's Rental Supply}

While it is clear that the cost of owning property has increased significantly, the affordability crisis is also felt deeply in the rental market. Although everyone is impacted by Toronto's housing crisis, it disproportionately affects certain groups such as refugee claimants as they have 
less access to resources and social capital when compared to other demographics (City of Toronto, 2019a). The remainder of this section provides an analysis of Toronto's rental market, which is often refugee claimants' entry point when trying to secure permanent housing.

Toronto's rental housing market is divided into two components - the primary rental market and the secondary rental market. The primary rental market includes rental units in privately initiated developments, purpose-built apartments and row house structures of three or more units. In contrast, the secondary rental market includes condominium rental housing, and noncondominium rental housing (CANCEA and CUI, 2019). The latter, in turn, is comprised of rented houses, secondary suites, social and affordable (non-market) rental housing (CANCEA and CUI, 2019). This differentiation is important in the context of refugee claimants, as they mainly depend on the primary market for purpose-built rentals, and on the secondary non-condo market for secondary suites and social housing during their search, as mentioned by service providers. This is primarily because of their limited financial capacity. Given their lower rental costs those components of the primary and secondary non-condo market provide a stronger possibility of getting a unit.

In the past few decades, the proportion of units that are primary rental has been slowly decreasing. Almost $66 \%$ of purpose-built rental housing in Toronto was developed between 1960-1979, during the rental apartment boom in the city (CANCEA and CUI, 2019). 93\% of all existing purpose-built rental housing was constructed before 1980, and less than 20,000 units have been developed in the primary rental market since then (CANCEA and CUI, 2019). This signifies a crippling decline of primary rental construction in recent decades, and in turn has driven the market to become less affordable as construction has not kept up with the demand (Social Planning, 2020). This decline in rental construction over the past few decades is significant as refugee claimants primarily target this market (City of Toronto, 2019a). Figure 2 below displays the rates of primary rental construction between 1960-2018. This graphic clearly displays that majority of primary rental units including affordable housing were built before 1980, with very few units built after that point. 
Without adequate supply and new construction of purpose-built rental units, refugee claimants are forced to look to the secondary non-condo market. Resorting only to the secondary noncondo market is problematic because of the long waitlist for social housing, which will be elaborated on below. This limited stock severely reduces the housing pool refugee claimants can access. However, Urbanation ${ }^{7}$ President Shaun Hilderbrand, reported that purpose-built apartment construction hit the highest levels since the 1970's in the last quarter of 2019, with a total of 12,367 apartment units being built (Toronto Star, 2020). Although these changes may not be felt anytime soon, if this trend continues it provides some hope for future years.

\section{Figure 2 - Rental Construction}

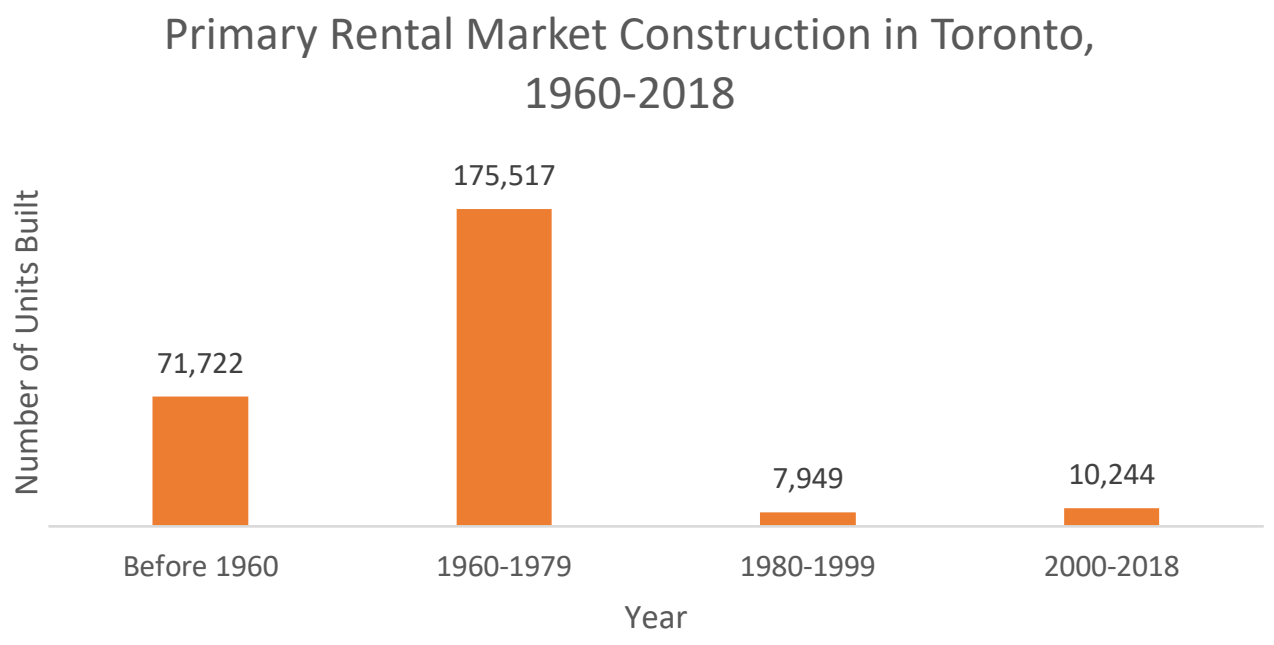

Source: CANCEA and CUI: From Insight to Action (2019).

\section{Low Vacancy Rates}

Furthermore, the rental vacancy rate is an indicator that measures the percentage of rental homes that are vacant. Most economists suggest a vacancy rate in a healthy market is $3.0 \%$ (RBC, 2019a). However, Toronto's vacancy rate is not within that bracket and has been decreasing over the years. Recent vacancy rates are $1.6 \%$ for bachelor units, $1.2 \%$ for 1-bedrooms, $0.9 \%$ for 2bedrooms, and $1.2 \%$ for $3+$ bedrooms (CMHC, 2019). Figure 3 displays the overall vacancy rates for all units by year. In 2012, the vacancy rate was at $1.7 \%$ and remained at this rate until 2016 when it dropped to $1.3 \%$, and in 2017 it dropped again to $1.0 \%$. Since 2017, it has

\footnotetext{
${ }^{7}$ Urbanation is a market research company that tracks development in the Toronto region.
} 
increased slightly and reached $1.5 \%$ in 2019. This shows that rental demand remains high in Toronto, and supply has not been able to keep up with this demand. This has added to the growing challenges Toronto renters are faced with during their search for suitable housing. The effects of such low vacancy rates are felt deeper by those with a lower socioeconomic status, such as refugee claimants. The low vacancy rates means that there are fewer units vacant on the market that prospective renters can apply to, increasing competition and subsequently impacting rental rates. Since refugee claimants primarily look to the rental market, this limited supply makes it increasingly difficult to find a unit within the city.

Figure 3 - Vacancy Rates

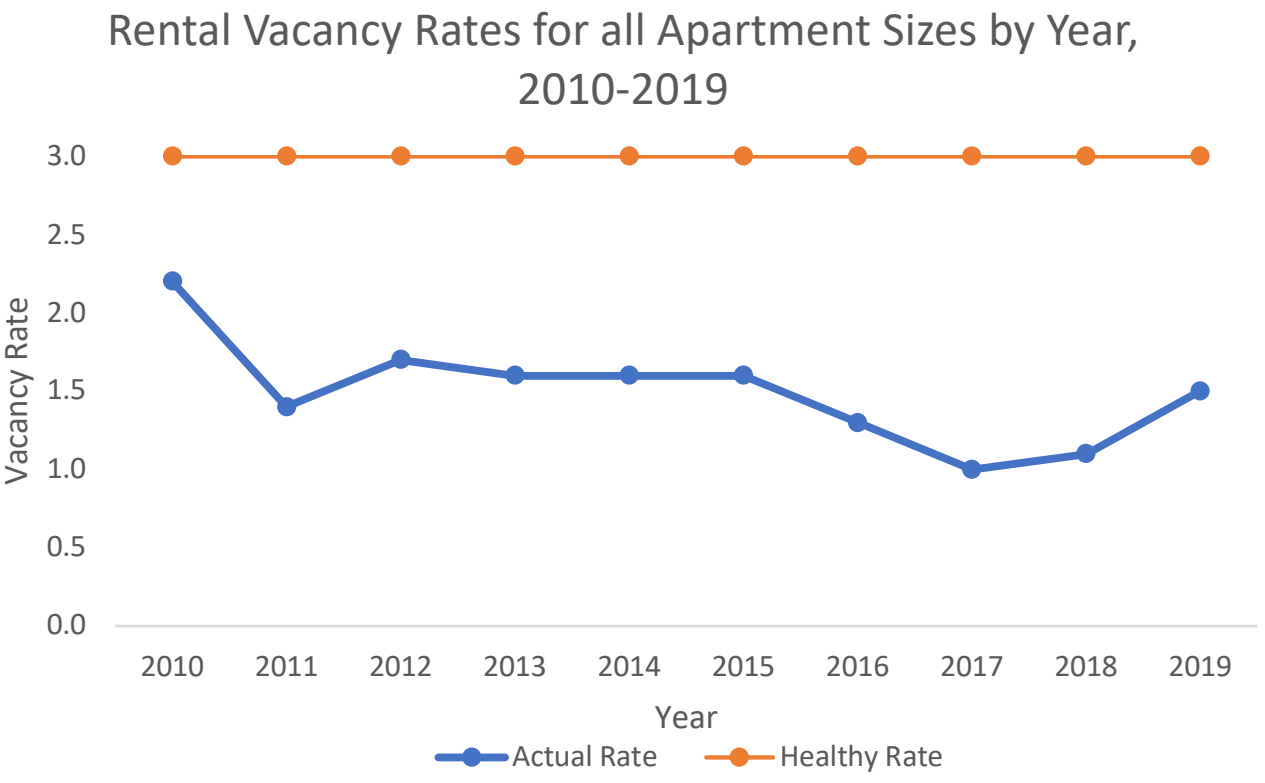

Source: CMHC 2010-2019 Rental Market Survey *all bedroom units includes bachelor, 1 bedroom, 2 bedroom, and 3 bedrooms.

\section{Growing Social Housing Waitlist}

In addition to the growing difficulty of obtaining market-rate rental units, Toronto's social housing waitlist has been increasing over the past decade. There are currently 110,677 households on the waitlist for social housing as depicted in Figure 4. The social housing waitlist has been steadily growing since 2012 , when the figure was at 85,578 , pointing to the growing need for more affordable housing within the city (City of Toronto, 2020b). The current waitlist results in an average waiting period of 10-12 years, however this could be longer based on the unit size requested (City of Toronto, 2020b). The waitlist has been growing significantly and this 
is in large part a result of the federal and provincial government's downloading of responsibility for affordable housing to municipalities in the late 90's (Hulchanski, 2003). This decision coupled with insufficient rental construction has created longer social housing waitlists.

Figure 4-Social Housing Waitlist

Size of Social Housing Waitlist in Toronto, 2012-2019

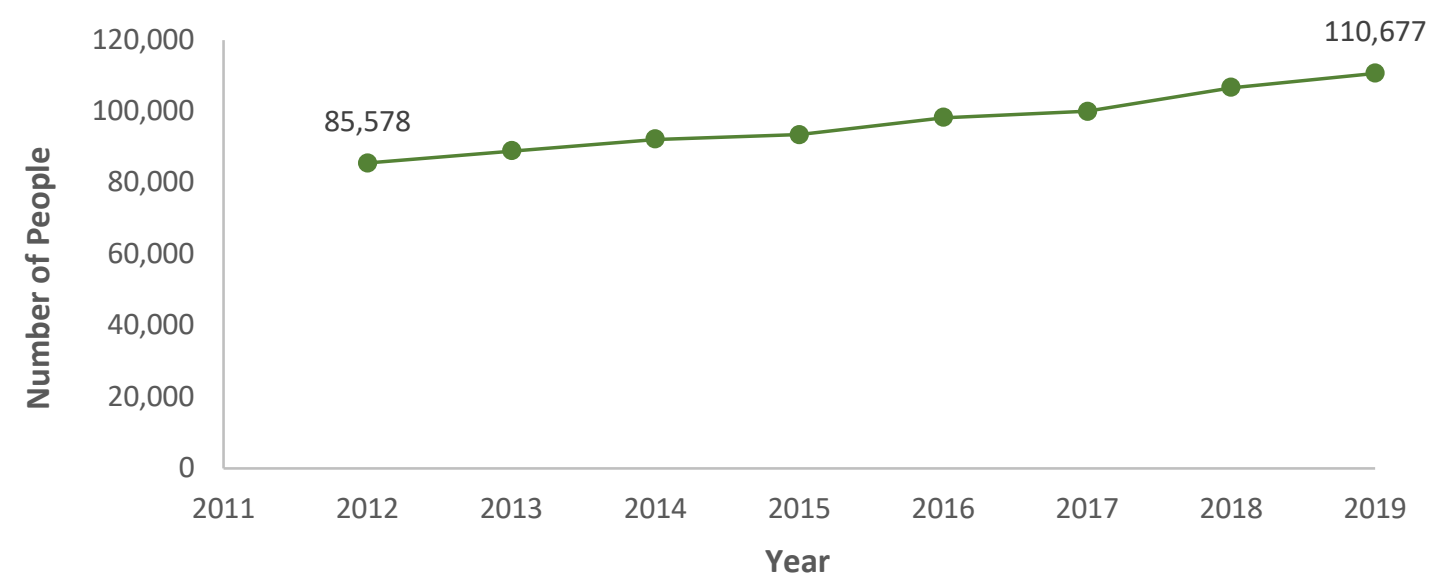

Source: City of Toronto, Toronto Progress Portal 2020

\section{Rental Rates in Toronto}

A recent City of Toronto report found that unaffordability is the key driver of core housing need in Toronto (City of Toronto, 2018). The 2016 Census also revealed that $37 \%$ of Toronto households spend more than $30 \%$ of their before-tax income on basic shelter (City of Toronto, 2018). There are far more tenant households living in unaffordable housing in comparison to owner households, the rates being $47 \%$ and $27 \%$ respectively (City of Toronto, 2019c).

Figure 5 displays the number of private market renter households with pre-tax household incomes less than $\$ 30,000$. According to the Canadian Mortgage and Housing Corporation, households that spend more than $30 \%$ of their income on shelter are in core housing need, while those that spend $50 \%$ or more on shelter are in severe housing need (CMHC, 2019). Figure 5 shows that approximately $87 \%$ of renter households living in the private rental market were spending more than $30 \%$ of their income on shelter. There were 15,730 households paying less than $30 \%$ of their income on shelter, while 106,355 were paying over $30 \%$. This displays that once families secure a lease, the challenge shifts from finding housing to keeping up with the 
high costs of rent. As such, refugee claimants like other underserved demographics with low incomes are likely to continue facing barriers until their socioeconomic status improves and they earn a higher income.

Figure 5-Renter Shelter Costs

\section{Renter Households Monthly Shelter Cost in Toronto in $2016(<30,000$ Pre-Tax)}

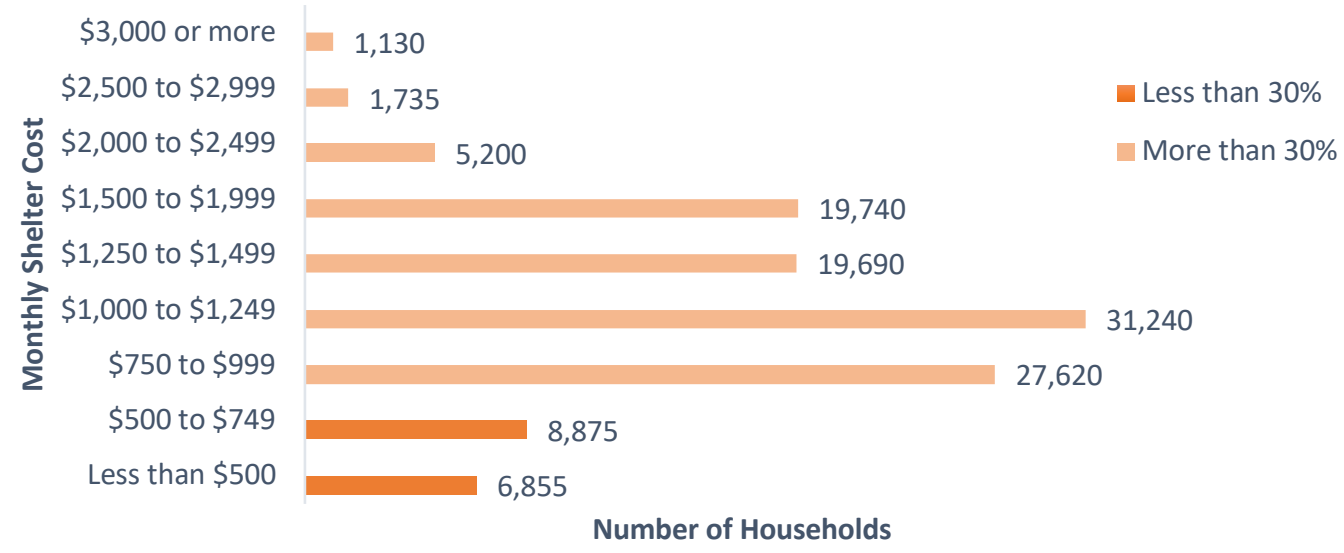

Source: Statistics Canada, 2016 Census of Population, From Insight to Action 2020

Table 3 - Household Spending

\begin{tabular}{|c|c|}
\hline \# of Households Spending less than $30 \%$ & \# of Households Spending more than $30 \%$ \\
\hline $\mathbf{1 5 , 7 3 0}$ & $\mathbf{1 0 6 , 3 5 5}$ \\
\hline
\end{tabular}

Source: Author based on data from 2016 Census of Population, From Insight to Action (2019).

Furthermore, data from the CMHC Rental Market Survey displays that average rents between 2010 and 2018 have risen by $39.8 \%$ for bachelor units, $33.7 \%$ for 1 -bedrooms, $31.6 \%$ for 2 bedrooms, and $23.6 \%$ for $3+$ bedrooms in the primary rental market (CMHC, 2010-2019). In comparison, the inflation rate over the same time period was only 13.62\% (CMHC, 2010-2019). Figure 6 displays the annual average rent rates for 1-bedroom apartments, 2-bedroom apartments and 3-bedroom apartments. Thus, pushing some people to the outskirts of the city or the GTA to find housing that is more suitable and affordable. This data also reveals that despite inflation rate only being $13.62 \%$, the cost of housing increased dramatically since 2010 . The unaffordability 
has in turn resulted in hundreds of thousands of households spending most of their income on rent as displayed in Figure 5, and also living in precarious housing (CMHC, 2010- 2019).

Figure 6-Average Rent for Bedroom Units

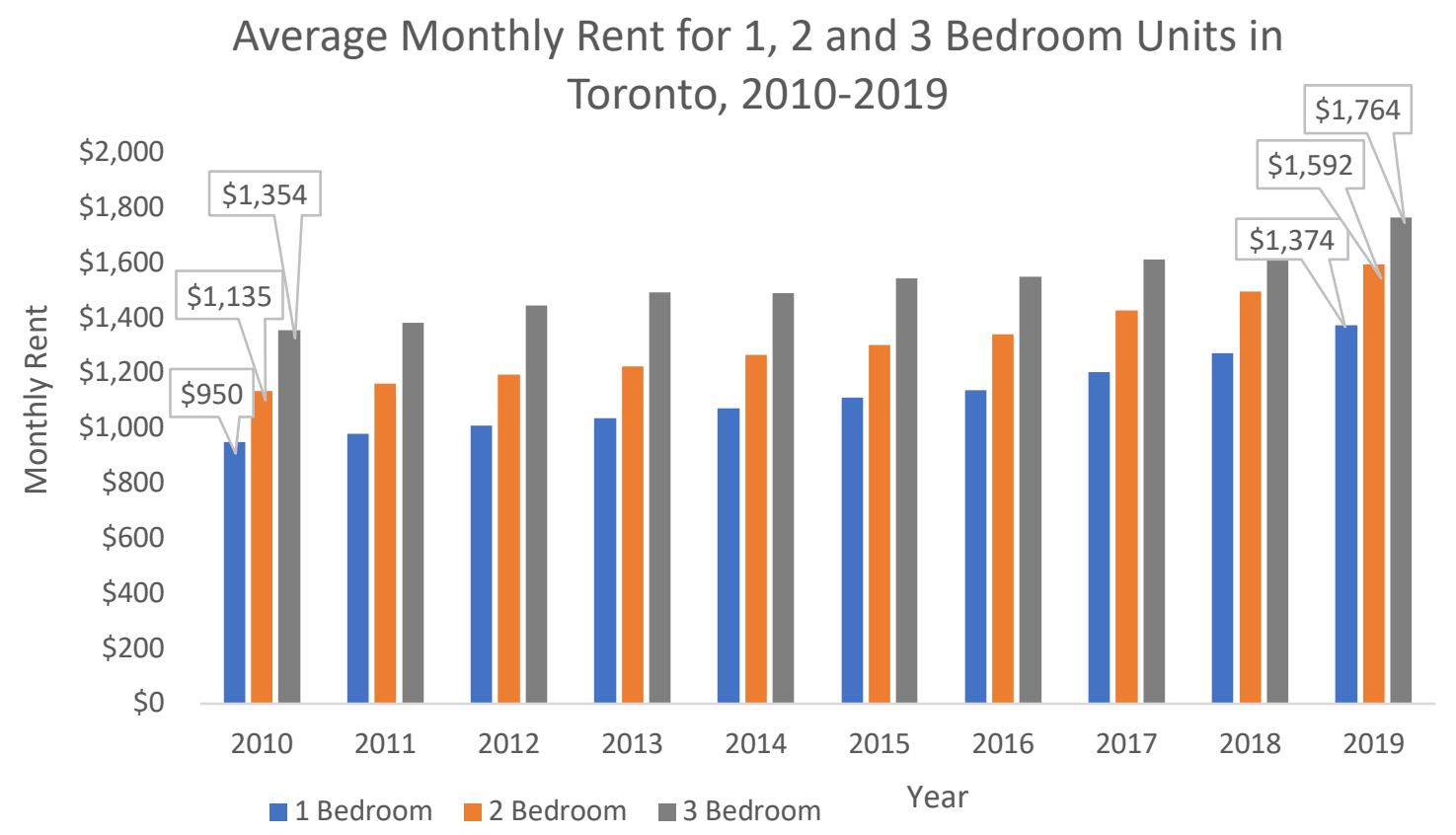

Source: CMHC 2010-2019 Rental Market Survey

Table 4 - Increase in Rental Rates from 2010-2019 for 1, 2-and 3-Bedroom Units in Toronto

\begin{tabular}{|l|c|c|c|}
\hline & Average Rent 2010 & Average Rent 2019 & Percentage of Increase \\
\hline 1 Bedroom & $\$ 950$ & $\$ 1,374$ & $44.6 \%$ \\
\hline 2 Bedroom & $\$ 1,135$ & $\$ 1,592$ & $40.2 \%$ \\
\hline 3 Bedroom & $\$ 1,354$ & $\$ 1,764$ & $30.2 \%$ \\
\hline
\end{tabular}

Source: Author based on information from CMHC 2010-2019 Rental Market Survey

Below is a comparison of rental increases in the secondary condo market. The only available data online for secondary condo was from 2017 and only for the Toronto CMA not the census subdivision. As a result, these two data sets cannot be compared directly against each other. However, the data for average rent in rental condominium apartments is noteworthy as it's significantly higher than the average of the primary rental market. For instance, in 2019 the average rent for a 2-bedroom apartment was $\$ 1,592$ in the primary market and $\$ 2,476$ in the secondary condo market (CMHC, 2018-2019). This significant difference in the two markets illustrates why the primary rental market is more desirable for refugee claimants, or the secondary non-condo market. 
Table 5 - Toronto Census Metropolitan Area Average Rents for Rental Condominium Apartments

\begin{tabular}{|c|c|c|}
\hline & Average Rent 2018 & Average Rent 2019 \\
\hline 1 Bedroom & $\$ 1,910$ & $\$ 1,966$ \\
\hline 2 Bedroom & $\$ 2,393$ & $\$ 2,476$ \\
\hline 3 Bedroom+ & $\$ 2,982$ & $\$ 2,829$ \\
\hline
\end{tabular}

Source: CMHC Secondary Rental Market Survey 2018-2019

\section{Declining Housing Standards}

Figure 7 below compares Canadian Mortgage and Housing Corporation housing standards levels in 2011 to 2016 (CMHC, 2016). CMHC identifies core housing need by recognizing houses that are unaffordable and fall below housing standards. CMHC outlines three housing standards: Adequate Housing, Suitable Housing and Affordable Housing. Housing is considered adequate if it does not need any major repairs according to residents. For instance, defective plumbing,

electrical wiring or structural repairs to walls, floors or ceilings would be a major repair. Housing is considered suitable if there are enough bedrooms for the size and make-up of resident households, and this is measured according to the National Occupancy Standard (CMHC, 2016). As mentioned earlier, housing is considered affordable if shelter costs equal to or are less than $30 \%$ total before-tax household income. Figure 7 displays that there are more households that are below affordability, adequacy and suitability standards in 2016 when compared to 2011 . The most significant increase was the growth in households below suitability standards, which increased by almost $10 \%$. 


\section{CMHC Housing Standards in 2011 and 2016}

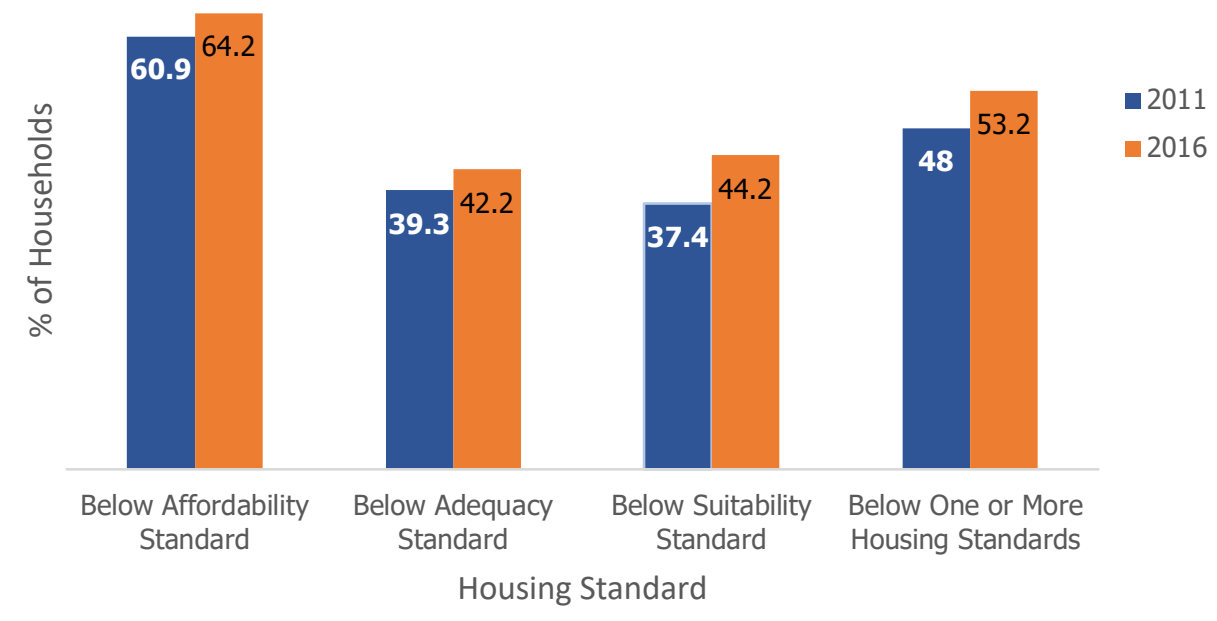

Source: CMHC Historical Housing Standards 2011-2016

\section{Conclusion}

In sum, it is evident that Toronto's housing market has become significantly less affordable than it was almost ten years ago when the Preston study was conducted, as illustrated by the analysis presented in this section. Different components of the restrictive housing market that were not as obvious a decade ago - such as low vacancy rates, higher rates of rent, and larger social housing waitlist - have amplified the struggles refugee claimants face in their search for housing. Therefore, one can assume that refugee claimants participating in Preston's study searched for housing in a less constrictive market, in comparison to those that service providers have referred to in this study. While there are many contributing factors, which have made the rental and ownership markets less affordable, the purpose of my research is not to determine what has caused this affordability crisis but rather to understand the effects of this market on the housing experiences of refugee claimants. The next section will provide an overview of the current refugee housing situation. 


\subsection{Programs and Funding}

\section{Funding}

The federal government and the Ministry of Immigration and Citizenship provide funding for settlement and integration services, but not all refugee classes are eligible to receive the services (Government of Canada, 2019c). For instance, only newcomers with permanent resident status (GARs and PSRs) are eligible for federally funded services, while services funded by provincial ministries are available to permanent residents as well as to refugee claimants (Government of Canada, 2019c).

Privately sponsored refugees receive financial support for 12 months by the sponsoring group, and government-assisted refugees receive financial support from the federal government for their first 12 months in Canada. The Resettlement Assistance Program (RAP) funded by the federal government provides income support to Government-Assisted Refugees and Privately Sponsored Refugees who were admitted to Canada under a cost-sharing/blended initiatives program (Government of Canada, 2019b). This support is intended to ease the settlement process for the above-mentioned groups. However, refugee claimants are not eligible. The program has two main components: income support and the provision of a range of immediate essential services. The income support part is further divided into start-up allowances and monthly income support. Start-up allowances include a one-time payment intended to cover the initial costs of settling in Canada for GAR's (Government of Canada, 2019b).

Past studies have indicated that refugee claimants experience a more challenging housing trajectory when compared to PSR's and GAR's, and Table 6 shows one of the contributing factors: social assistance programs. The table displays the rates for the RAP program and differentiates between family size. GAR's are eligible for programs like RAP, which provide more financial and social support, thus improving the conditions under which GAR's looks for housing. Ultimately, this is a big distinguishing factor between GAR's and refugee claimants, as the latter group does not have access to the same services and thus experience greater difficulties in their search for permanent housing. 
Table 6 - Ontario Resettlement Assistance Program Rates

\begin{tabular}{|l|l|l|l|l|}
\hline Family Size & \multicolumn{1}{|c|}{$\begin{array}{c}\text { Household } \\
\text { Composition }\end{array}$} & $\begin{array}{c}\text { Basic Needs } \\
\text { Allowance }\end{array}$ & $\begin{array}{c}\text { Shelter } \\
\text { Allowance }\end{array}$ & \multicolumn{1}{c|}{$\begin{array}{c}\text { Communication } \\
\text { Allowance }\end{array}$} \\
\hline 1 & Single Adult & $\$ 343$ & $\$ 390$ & $\$ 30 /$ file \\
\hline 2 & Couple & $\$ 494$ & $\$ 642$ & $\$ 30 /$ file \\
\cline { 2 - 6 } & $\begin{array}{l}\text { Single parent plus } \\
\text { one child }\end{array}$ & $\$ 360$ & $\$ 642$ & $\$ 30 /$ file \\
\hline 3 & $\begin{array}{l}\text { Single parent plus } \\
\text { two children }\end{array}$ & $\$ 360$ & $\$ 697$ & $\$ 30 /$ file \\
\cline { 2 - 6 } & $\begin{array}{l}\text { Couple plus one } \\
\text { child }\end{array}$ & $\$ 494$ & $\$ 697$ & $\$ 30 /$ file \\
\hline 4 & $\begin{array}{l}\text { Single parent plus } \\
\text { three children }\end{array}$ & $\$ 360$ & $\$ 756$ & $\$ 30 /$ file \\
\cline { 2 - 6 } & $\begin{array}{l}\text { Couple plus two } \\
\text { children }\end{array}$ & $\$ 494$ & $\$ 756$ & $\$ 30 /$ file \\
\hline 5 & $\begin{array}{l}\text { Single parent plus } \\
\text { four children }\end{array}$ & $\$ 360$ & $\$ 815$ & $\$ 30 /$ file \\
\cline { 2 - 6 } & $\begin{array}{l}\text { Couple plus three } \\
\text { children }\end{array}$ & $\$ 494$ & $\$ 815$ & $\$ 30 /$ file \\
\hline 6 or more & $\begin{array}{l}\text { Single parent plus } \\
\text { five children }\end{array}$ & $\$ 360$ & $\$ 844$ & $\$ 30 /$ file \\
\cline { 2 - 5 } & $\begin{array}{l}\text { Couple plus four } \\
\text { children }\end{array}$ & $\$ 494$ & $\$ 844$ & $\$ 30 /$ file \\
\hline
\end{tabular}

Housing Supplement: up to a maximum of \$200, may be issued when actual housing expenses exceed the basic shelter allowance. If the RAP file is still open at time of receipt (no retroactive payments will be made). In order to be considered for this allowance, refugees must submit to IRCC documentation, such as a lease agreement, indicating that their total housing costs (including utilities) exceed the maximum shelter allowances issued under RAP.

\begin{tabular}{|l|l|l|}
\hline \multicolumn{3}{|c|}{ Special Allowances } \\
\hline Allowance & Frequency & Rate \\
\hline Maternity Food & Monthly & $\$ 75$ \\
\hline Maternity Clothing & One-time & $\$ 200$ \\
\hline Newborn Allowance & One-Time & $\$ 750$ \\
\hline Dietary Allowance & Monthly & $\$ 75$ \\
\hline $\begin{array}{l}\text { FuneraVBurial } \\
\text { Allowance }\end{array}$ & $\begin{array}{l}\text { Costs are } \\
\text { reviewed case by } \\
\text { case based on } \\
\text { provincial rates. }\end{array}$ \\
\hline $\begin{array}{l}\text { Note: Refugees can request a special dietary allowance of } \\
\text { \$75/month (per family) if they provide a doctor (or nurse } \\
\text { practitioner's) note indicating they have a medical condition } \\
\text { requiring a specialized diet. If the RAP file is still open at time of } \\
\text { receipt (no retroactive payments will be made). }\end{array}$
\end{tabular}

Blended Visa Office-Referred Program (BVORs)

Refugees sponsored through the BVOR Program are eligible for the following income support benefits:

- Food and incidentals (basic needs),

- Basic shelter,

- Communication allowance

- Transportation,

- Housing Supplement (if applicable)

- Matemity food allowance (ifapplicable)

- Special dietary allowance (ifapplicable)

The remaining costs, including start-up and additional special expenses as required, are covered by the sponsoring group.

Source: Government of Canada, 2019

In contrast, refugee claimants do not receive any financial support from the federal government during their time in Canada. Instead, they can apply for Ontario Works, a provincially funded program that provides financial support until they receive permanent resident status. The rates for Ontario Works are displayed in Table 7. Refugee claimants enter Canada without refugee status and have their claim adjudicated in Canada. It takes 20 months on average before they receive a first level decision (City of Toronto, 2018). This extended decision period has enticed the City of Toronto to request the federal government to speed up processing times for refugee claimants (City of Toronto, 2018). Additionally, refugee claimants are often forced to wait several months before they can begin working, as the process of obtaining a work permit can be lengthy (Government of Canada, 2020b).

Through this quick overview, it is evident that compared to GARs and PSRs refugee claimant families are not earning nearly enough to cover both the cost of shelter and other expenses such 
as travel, food and clothing. For instance, a couple with one dependent would earn $\$ 494$ for basic needs and $\$ 697$ for shelter allowance, totalling $\$ 1,191$ for a family of three. As indicated in Section 6.0 the average cost of rent for a 1-bedroom unit in Toronto is around $\$ 1,374$. Therefore, when observing rates received from Ontario Works and comparing them against the current housing market, it is clear that the social assistance rates are not sufficient for those refugee claimants living in Toronto. The amount received from OW does not cover the cost of rent, and this is not accounting for other household expenses.

Table 7- Ontario Works Rate Chart

\section{[10 Torontomployment \& Social Services ONTARIO WORKS (OW) RATE CHART OCTOBER 1, 2018}

\begin{tabular}{|c|c|c|c|c|}
\hline \multicolumn{5}{|c|}{ BASIC NEED (Renters/Owners) } \\
\hline $\begin{array}{l}\text { Number of } \\
\text { Dependants } \\
\text { other than a } \\
\text { Spouse }\end{array}$ & $\begin{array}{l}\text { Dependants } \\
\text { 18 Years or } \\
\text { Older }\end{array}$ & $\begin{array}{l}\text { Dependants } \\
\text { 0-17 Years }\end{array}$ & Single & Couple \\
\hline 0 & - & - & $\$ 343$ & $\$ 494$ \\
\hline 1 & - & 1 & 360 & 494 \\
& 1 & - & 623 & 652 \\
\hline 2 & - & 2 & 360 & 494 \\
& 1 & 1 & 623 & 652 \\
& 2 & - & 781 & 826 \\
\hline 3 & - & 3 & 360 & 494 \\
& 1 & 2 & 623 & 652 \\
& 2 & 1 & 781 & 826 \\
& 3 & - & 956 & 1001 \\
\hline
\end{tabular}

\begin{tabular}{|c|c|}
\hline Family Size & $\begin{array}{c}\text { Maximum Monthly Shelter } \\
\text { Allowance }\end{array}$ \\
\hline One & $\$ 390$ \\
\hline Two & $\$ 642$ \\
\hline Three & $\$ 697$ \\
\hline Four & $\$ 756$ \\
\hline Five & $\$ 815$ \\
\hline Six or more & $\$ 844$ \\
\hline
\end{tabular}

Source: Toronto Employment and Social Services (year

\section{Child-Benefit Funds}

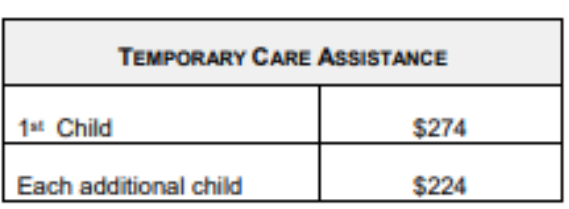

\begin{tabular}{|c|c|c|c|c|}
\hline \multicolumn{5}{|c|}{ MAXIMUM BoARD AND LodGING TABLE } \\
\hline $\begin{array}{l}\text { Dependants } \\
\text { (Dep) other } \\
\text { than a } \\
\text { Spouse }\end{array}$ & $\begin{array}{l}\text { Dep } \\
\text { aged } \\
18 \text { or } \\
\text { older }\end{array}$ & $\begin{array}{l}\text { Dep } \\
\text { aged } \\
0-17\end{array}$ & Single & Couple \\
\hline 0 & 0 & 0 & $\$ 533$ & $\$ 688$ \\
\hline 1 & 0 & 1 & 664 & 752 \\
& 1 & 0 & 752 & 790 \\
\hline 2 & 0 & 2 & 737 & 813 \\
& 1 & 1 & 825 & 851 \\
& 2 & 0 & 873 & 887 \\
\hline 3 & 0 & 3 & 806 & 874 \\
& 1 & 2 & 894 & 912 \\
& 2 & 1 & 942 & 948 \\
\hline
\end{tabular}

For each additional dependant of a sole support parent add $\$ 120$ if the dependant is 18 years of age or older or add $\$ 69$ if the dependant is $0-17$ years of age.

Otherwise, for each additional dependant add $\$ 100$ if the dependant is 18 years of age or older or add $\$ 61$ if the dependant is $0-17$ years of age.

\begin{tabular}{|c|c|}
\hline \multicolumn{2}{|c|}{ Dependant(s) of Dependant } \\
\hline $\begin{array}{c}\text { Number of Dependant } \\
\text { Children }\end{array}$ & Entitlement \\
\hline 1 & $\$ 366$ \\
\hline 2 & $\$ 419$ \\
\hline 3 & $\$ 479$ \\
\hline 4 & $\$ 537$ \\
\hline 5 or more & $\$ 568$ \\
\hline
\end{tabular}

Special Boarder Allowance $\$ 71$ per benefit unit (Applicable for board \& lodging and financially independent adults)

Advanced Age Item $\mathbf{\$ 4 4}$ (For each member of the benefit unit who is 65 years of age or older) 
It is also important to note that refugee claimants do not receive the Ontario Child Benefit, unlike Government Sponsored Refugees and Privately Sponsored Refugees. Instead, they can apply for the Transitional Child Benefit (Government of Canada, 2020d). This program is available to those who are not citizens or permanent residents of Canada, such as refugee claimants. The most Transitional Child Benefit (TCB) that a family can get is $\$ 230$ each month for each of their children, and this is notably less than the amount permanent residents receive for child benefit. Permanent residents receive funds from two streams, the Federal Child Benefit and Ontario Child Benefit (OCB). Families may receive up to $\$ 119.50$ per month from OCB for each child that is under 18 years old. However, this figure is dependent on net income and may fluctuate. The Federal Child Benefit is about $\$ 553$ per month for each child under the age of 6 , and $\$ 466.83$ for children over 6 and under 18. Therefore, adding the Federal Child Benefit and the Ontario Child Benefit amounts together is higher than what refugee claimants get from the Transitional Child Benefit. However, it is important to note that this figure can decrease if a family's net income is over $\$ 31,120$. From this high-level examination, it is clear that refugee claimants face even greater challenges, as the amount of funding they receive for eligible children is significantly lower than other immigrant groups. In turn, this makes it increasingly difficult to find housing with the limited capital they have. As refugee claimants receive less government funding for their children in comparison to permanent residents, GAR's and PSR's,

is it without a doubt more challenging for them to find housing. They are competing for the same units as the aforementioned groups, but with less financial power and stability.

\section{Toronto-Based Programs}

In addition to the federal and provincial funding sources just described, during the interviews with service providers some Toronto-based programs were mentioned as being relevant to the experience of refugee claimants in the city, including the Housing Stabilization Fund (HSF) and the Housing Allowance fund. As the following section elaborates in greater detail, both programs provide access to a critical source of funding for refugee claimants. 
HSF is an integral part of Ontario's Long-Term Affordable Housing Strategy ${ }^{8}$ and combines provincial funding from five existing homelessness programs into a single funding program. HSF is a program delivered by the City of Toronto Employment and Social Services (TESS) division and has been operating since January $1^{\text {st }}, 2013$ (City of Toronto, n.d)The main goal of this funding program is to meet the emergency housing needs of Toronto residents who receive social assistance in order to stabilize their housing situation. The general principles of this program are to provide assistance to residents who are experiencing homelessness or those who are experiencing a high-rent situation to relocate or retain housing (City of Toronto, n.d.). While this program is not designed to address all of the complex needs of clients, it is an important step in their stabilization process. This program has not been designed specifically for refugee claimants, but they are listed as an eligible group.

Below is a chart that identifies some components of HSF that would apply specifically to refugee claimants, provides details and outlines exclusion criteria. Some components indicate a specific amount of funding while others may be determined on a case-by-case application. Through this, it can be seen that refugee claimants are able to apply for the last month program, for furniture allowance and to help with moving costs within the GTA (City of Toronto, n.d.). Eligible groups need to apply for the different programs they are interested in on their own, and most of the funds are paid on a one-time basis.

\footnotetext{
${ }^{8}$ In 2010, Ontario launched the Long-Term Affordable Housing Strategy, Building Foundations: Building Futures. The strategy began a process of transforming Ontario's housing system into one that is people-centred, partnershipbased, locally driven, and fiscally responsible.
} 
Table 8 - City of Toronto Housing Stabilization Fund Components and Details

\begin{tabular}{|c|c|c|c|}
\hline $\begin{array}{c}\text { Housing } \\
\text { Stabilization } \\
\text { Fund } \\
\text { Components }\end{array}$ & Details & $\begin{array}{l}\text { Exclusion } \\
\text { Criteria }\end{array}$ & Amounts \\
\hline $\begin{array}{l}\text { Last Month } \\
\text { Rent }\end{array}$ & $\begin{array}{l}\text { Funds to secure an address will be issued if } \\
\text { accommodation costs are within } 85 \% \text { of } \\
\text { the total monthly income. } \\
\text { Funds are payable to landlord/property } \\
\text { owner. }\end{array}$ & $\begin{array}{l}\text { Not issued to } \\
\text { applicants } \\
\text { who are } \\
\text { subletting or } \\
\text { listed as an } \\
\text { occupant } \\
\text { only. }\end{array}$ & N/A \\
\hline $\begin{array}{l}\text { Establishing a } \\
\text { Residence }\end{array}$ & $\begin{array}{l}\text { To purchase household items to establish a } \\
\text { residence within the City of Toronto for } \\
\text { clients moving from street, a shelter, or a } \\
\text { furnished to unfurnished accommodate, } \\
\text { and new residents who are establishing an } \\
\text { accommodation. }\end{array}$ & N/A & $\begin{array}{l}\text { Singles/Couples: } \\
\$ 800 \\
\text { Families with } \\
\text { Dependent } \\
\text { Adults: } \$ 1000 \\
\text { Families with } \\
\text { Children: } \$ 1500\end{array}$ \\
\hline $\begin{array}{l}\text { Moving Costs } \\
\text { within the } \\
\text { GTA }\end{array}$ & $\begin{array}{l}\text { Funds for moving will be issued if the } \\
\text { client is housed and moving within the } \\
\text { GTA due to a high rent situation, eviction } \\
\text { or to accommodate a change in family size. }\end{array}$ & N/A & $\begin{array}{l}\text { Singles/Couples: } \\
\$ 350 \\
\text { Families: } \\
\$ 425\end{array}$ \\
\hline
\end{tabular}

Source: City of Toronto Housing Stabilization Fund

Similarly, the Housing Allowance is a non-repayable City of Toronto housing subsidy that assists eligible households in paying monthly rent, including refugee claimants (City of Toronto, n.d). This program provides the funds directly to the individual, not the landlord. Direct payments to individuals provide more flexibility, as they can be used in the private market, are portable and can move where the tenant moves. Unlike Rent-Geared-to-Income (RGI) ${ }^{9}$ funding,

\footnotetext{
9 "Rent-Geared-to-Income (RGI) refers to a system of public subsidy in which rents in designated social housing units are set at a fixed percentage (approximately 30\%) of gross household income. RGI is specifically targeted toward low-income renter households and eligibility is determined on the basis of income and/or need. Housing programs that produced RGI units were terminated in the 1990s. Today, most new subsidized rental housing is
} 
this subsidy is not tied to the unit itself so recipients can move within the City and continue to receive the funds. The current target group for this program is people experiencing chronic homelessness (including refugee claimants), and it is expected that these applicants are homeless for at least six months while also meeting other eligibility criteria as outlined on the website (City of Toronto, n.d.). The Housing Allowance provides a fixed monthly subsidy until March $31^{\text {st }}, 2024$, upon confirmation of eligibility every year. There is no specific amount stated on the website, and applications may receive different amounts depending on family make-up, financial situation and rental rate. However, this was also brought up during interviews with service providers and it was mentioned that it is often a significant amount, upwards of $\$ 400$, that is provided to eligible applicants.

In sum, there are clear discrepancies between the types of programs and funding that different refugee groups are eligible for. Eligibility for programs such as Ontario Works, the Resettlement Assistance Plan, the Canada and Ontario Child Benefit, and Transitional Child Benefit have a significant impact on the housing trajectory of different refugee groups as the amount of funding received can differ greatly between GAR's, PSR's and refugee claimants. As such, lack of funding from these programs coupled with the affordability crisis in Toronto make it increasingly difficult for refugee claimants to find suitable housing.

\subsection{Interviews}

The interviews with service providers were analyzed to identify main themes. Interviews revealed that refugee claimants experience a variety of obstacles in their search for permanent housing and have developed unique coping mechanisms to navigate their challenging housing situation.

This study adds to the growing body of literature that analyzes the challenges refugee claimants experience in their search for permanent housing in large metropolitan cities like Toronto. Findings from this study reinforce major themes identified in past studies, and also brought to

affordable rental housing - that is, housing in which rents are set according to rents prevailing in the private market (rather than the incomes of households)" (CANCEA and CUI, 2019). 
light new trends in challenges and coping mechanisms. These findings build on the methodological path of the Preston study and continue the conversation on key themes that were identified in 2011. Key barriers that were highlighted in Preston's study were affordability, discrimination, overcrowding, household composition and size, and language. While several themes that emerged in Preston's study were revalidated through conversations with service providers in my study, new themes have emerged as well. For instance, both the Preston study and my study highlighted housing affordability and discrimination as major barriers.

Furthermore, service providers revealed that refugee claimants experience a variety of obstacles in their search for permanent housing and have developed unique coping mechanisms to navigate these challenges. The challenges faced by refugee claimants mirror findings from past qualitative studies like Preston et al., with more adaptions to alleviate pressures from Toronto's housing market. The Preston study identified two major themes in relation to coping mechanisms: the first was help from their own communities, and the second was temporary housing. In contrast, my research identified that sharing accommodation and looking beyond the GTA are evident coping strategies.

\subsubsection{Barriers}

\section{Housing Market \& Affordability}

Toronto's housing market and affordability were highlighted as the most significant barrier in finding permanent housing by all seven interviewees. Service providers pointed to the growing affordability crisis in the city that has made it increasingly challenging for refugee claimants to find adequate housing. Affordability was also identified as a major barrier by the Preston study, as service providers stated that many of their clients paid as much as $70 \%$ to $80 \%$ of their incomes on rent, as housing costs were increasing faster than social assistance rates at the time (Preston et al., 2011). Similarly, in today's context the cost of rent has gone up significantly and proves to be out of reach for most refugee claimants, which is a reflection of the housing market crisis described earlier. As identified in Section 6.1, Toronto's housing market has become increasingly unaffordable over the past decade. In 2012, the city was not facing an affordability 
crisis, vacancy rates were higher ${ }^{10}$ and the social housing waitlist was much shorter ${ }^{11}$. However, all these factors coupled with the decline in rental construction have added to the challenges refugee claimants face in their search for housing.

In addition to the cost of rent, the demand for rental units is extremely high as there has been very little rental construction over the past few decades. As a result, refugee claimants along with other Torontonians look towards the secondary non-condo rental market - like basement apartments - for housing that may be more within financial reach. Looking to the secondary rental market, refugee claimants are often competing with other applicants who are not on Ontario Works or have permanent resident status and as a result, their applications get rejected. As Service Provider 3 stated:

I had connections with one realtor, who you know tells me just for one basement apartment I receive 100's of applications so it is very competitive, and of course landlords are very selective and prefer families who are already working, have credit history than those who have just recently arrived and receive OW.

This quote suggests that refugee claimants are competing against other groups (immigrant or not) for the same rental units, which diminished their chances of finding permanent housing. Their applications are compared against others whom landlords deem as more qualified based on their immigration status, employment status and credit history. Low supply of rental housing has indirectly created competition among different refugee groups who are all in search of rental housing that is adequate and affordable.

Other participants mentioned that some refugee claimants are fearful of not finding housing at all because of the high rental rates, and as a result they do not bother to look for housing. Rather, they stay at the shelter where they are provided with meals and accommodation, free of charge. Staying at hotels that have been transformed into shelters allows refugee claimants to build a network with other claimants that they can connect to on a personal level. These factors provide refugee claimants with greater feelings of security and safety, enticing some to stay at the shelter.

\footnotetext{
10 The vacancy rate for all bedroom types was $1.7 \%$ in 2012 , and $1.5 \%$ in 2019 .

11 There were 85,578 people on the Social Housing Waitlist in Toronto in 2012, and that number increased to 110,677 in 2019.
} 
Service providers further mentioned that unaffordability and the housing market make it increasingly difficult for them to assist refugee claimants because their efforts are often undermined by market effects. As Service Provider 3 stated: "A single mother with children if total income is $\$ 1400$ and rent is $\$ 1800$ - they don't have enough money and its one of the biggest challenges we are facing as a service provider."

This quote further reveals the pressure of Toronto's rental market, as incomes are not keeping up with the price of rent. This is especially true for more underserved populations like refugee claimants. As a result, families with income that is not sufficient for rent are obligated to look towards unsatisfactory units because of the lower price point they offer.

A related challenge has to do with family make-up. Several service providers mentioned that single parents face a more difficult path to finding permanent housing because unlike dualincome families, single parents earn far less while having the same child-rearing responsibilities. Therefore, affordability issues are felt deeper by single parents, as they do not have the bonus of relying on their partner to look for employment/supervise children. For instance, Service Provider 1 stated: "The housing market, it is out of control, there is no availability in any kind of affordable housing, giving people more financial assistance is a great but it's just a band-aid solution, won't solve the problem."

This quote further reveals the strain Toronto's housing market has had on refugee claimants, and the complexity of the issue which cannot merely be solved by providing more funding. While there are funding programs in place like the HSF and Housing Allowance, a far more sophisticated solution is required to mitigate the impacts of this impediment.

The Preston study also found that service providers were frustrated by the shortage of subsidized housing. In my research, service providers stated that refugee claimants have mentioned that they knew moving to another country was challenging because of things like employment, culture shock, adaptation but they never thought housing would be such a significant challenge here. This can also be a result of a lack of knowledge of local housing markets before entering Toronto. Perhaps, if there is more publicly available information online that claimants can look 
to when deciding which city to settle in, the severity of this problem can be mitigated if some refugee claimants chose alternative destinations instead of continue to saturate Toronto's housing market.

\section{Employment}

In addition to affordability and a limited rental housing market, another factor that was highlighted as a barrier to finding housing was employment. Almost all service providers discussed role of employment in finding housing, noting they go hand in hand. The first obstacle in the process of obtaining employment is the ability of refugee claimants to secure a work permit. Refugee claimants can apply for a work permit when submitting their application for permanent residency, but this process can take months. ${ }^{12}$ In the meantime, they are not legally allowed to work in Canada, and this is a process that can last up to 4 months as Service Provider 3 mentioned. Rather than waiting for their work permit documents some refugee claimants will work "under the table" because of their desperate financial state, and this often results in employers taking advantage of them. This was captured by Service Provider 6, who told me:

I have some clients that told me they are working below minimum wage, long hours without a break and poor working conditions because they have no choice and need to make a living, and all the money they end up making goes to rent.

Clients that had secured any form of employment were more likely to secure housing sooner. Access to this additional source of income has proven to be critical for refugee claimants, as the amount they receive for social assistance is not sufficient and this income is an important supplement to that. However, because of their refugee status coupled with a lack of "Canadian experience" refugee claimants are often engaging in precarious and informal work to earn an extra income. Securing any type of employment brings in an extra income, which reduces housing affordability challenges significantly. The importance of employment in finding housing

\footnotetext{
12 "A refugee claimant can apply to Immigration, Refugees and Citizenship Canada (IRCC) for a work permit by checking a box in form Schedule 12. Once a claimant is found eligible for a refugee protection hearing, they must complete a medical examination. Once this is received, IRCC can issue a work permit. If a refugee claimant did not apply through the Schedule 12 form, they can apply for a work permit later by showing they cannot support themselves through work" (CLEO, 2019).
} 
was also captured by Service Provider 1, who stated: "Housing is our number one priority but sometimes housing will not happen until employment does."

This quote reveals that often times the efforts of service providers in finding permanent housing for refugee claimants are limited because of the complexities of finding employment for them as well. As such, despite the devotion of these service providers in finding adequate housing for their clients, without having another source of income it is extremely difficult for refugee claimants to find appropriate housing within their budget.

One factor that undermines the ability of refugee claimants to find housing is their immigration status, because of the stigma associated with it. As Service Provider 7 stated: "Status as a refugee claimant is a big barrier in finding employment."

This statement reveals the additional hurdles refugee claimants face in their search for permanent housing. While obtaining employment is an important step in this process, the challenges in doing so cannot be simplified. Similar to applying for housing, refugee claimants are applying for the same jobs as other immigrant groups and permanent residents. Their status in Canada is assumed to be unstable by employers in addition to landlords.

Overall, the role of employment is vital in finding housing. On the one hand, having access to more financial means increases the capacity of refugee claimants to find housing. On the other hand, service providers mentioned that refugee claimants, despite their level of education or international experience, are content with any type of work they can secure as they understand that having an employment letter will help their housing applications immensely. When landlords review these applications, there may be some sense of security in knowing that there is another source of income in addition to Ontario Works/other funding opportunities, and it also shows initiative. While the Preston study found that employment discrimination was significant barrier for refugee claimants, the process of obtaining a work permit was not mentioned and therefore it is a new finding. This finding is important as it alludes to a barrier that, if mitigated through interventions that reduce work permit processing times, can significantly improve the ability of refugee claimants to find permanent employment and housing. The fact that this finding was not indicated in the Preston study may be a result of wait times being longer now, as 
there has been an influx of refugees over the past 5 years as described in Section 2.0. The influx

of claimants may have put a pressure on the Immigration and Refugee Board's ability to respond in a timely manner. As a result, the time it takes to obtain a work permit has been stretched.

\section{Discrimination}

Discrimination emerged as another barrier in refugee claimants' search for housing, a finding the Preston study also identified. The findings from Preston's study were more in-depth as they identified different forms of discrimination refugee claimants faced such as religion, age, gender, sex and employment. The findings from my research differ, as most of the aforementioned forms of discrimination were not mentioned. This discrepancy may also result from the differences in research design and the comprehensiveness of the interviews.

However, in my MRP interviews discrimination was still highlighted as a crippling factor in refugee claimants' search for permanent housing. Claimants face several forms of discrimination from landlords when applying for units, such as income discrimination and status-based discrimination. Landlords are sceptical of renting out units to refugee claimants because of the stigma attached to being on social assistance and their status as a refugee claimant. There is a strong misconception that this person's status is unknown, and they may leave at any point. According to the interviewees, landlords in both the primary and secondary rental market display similar behaviours and patterns when assessing applications from refugee claimants. Clients hear a wide range of excuses from landlords during meetings. For instance, Service Provider 1 stated that:

Landlords try to use [exploit] claimants by asking for 6 or 12 months of rent in advance, or they ask for a guarantor for someone that just came to Canada, which reduces the possibility of actually being able to secure.

While some landlords deliberately make excuses or ask for unattainable things that make it nearly impossible for refugee claimants to get the unit, other landlords do not shy away from explicitly stating that refugee claimants are not welcome. As Service Provider 3 mentions:

Especially in the private market with landlords, you will hear so many things where you are like I can't believe the landlord is like this, from these workers are telling clients saying we don't accept Ontario Works, we don't accept refugee claimants. 
In several interviews, service providers revealed that when their clients are stuck in such situations the service providers step up and take on an advocacy role. Service providers call these landlords to vouch for refugee claimants and try to convince them that the client has all the qualities of a great tenant. While this advocacy role is beyond their responsibilities as housing workers, they understand how prejudiced some landlords can be and are motivated to assist refugee claimants. However, even this vouching proves to be fruitless, as landlords will often give the units away to other applicants who have a more stable income source and a secure status. It was reported that some landlords make false promises to refugee claimants about repairing units before the move-in date. However, these repairs are often not completed. This causes a dreadful legal battle as some refugee claimants try to get back their initial deposit while others just accept the unit as is, knowing they have very little power.

Several interview participants also mentioned that landlords are not nearly as educated as they should be when it comes to the status of refugee claimants. The misconception of who a refugee claimant is is reflected in the comments they make to applicants. For instance, some landlords have told refugee claimants that there is too much uncertainty with their immigration status as they can leave at any moment, and others ask for employment letters before these individuals have received a work permit. As a result, some service providers encourage their tenants to refrain from saying the words "refugee claimant" and instead tell landlords that they are "newcomers". Additionally, it seems like some landlords are also not aware of the Residential Tenancy $\mathrm{Act}^{13}$ as they place specific conditions on tenants that are specifically prohibited. Educating landlords about the rights of tenants and the status of refugee claimants is critical in order to reduce discriminatory behaviours.

Findings from this study reinforce some of the findings from the Preston study, as that study concluded that landlords discriminate based on source of income, racial/ethno-religious affiliation, immigration status, gender and age. However, findings from my research revealed

\footnotetext{
13 The Residential Tenancies Act 2006 is the law in the province of Ontario, Canada, that governs landlord and tenant relations in residential rental accommodations. The Act received royal assent on June 22, 2006 and was proclaimed into law on January 31, 2007.
} 
discrimination against immigration status and income. The Preston study may have been more comprehensive as it compared results for several immigrant groups, and the sample size was larger, which may have allowed for more conversation regarding this theme. Nonetheless, it is certainly a theme that continues to persist and affect refugee claimants' capacity to secure housing. Preston's findings revealed discrimination against gender and religion, which are more covert and therefore complex to tackle through any sort of policy intervention. In contrast, income discrimination is more overt, and interventions can be geared towards this element specifically, such as streamlining the process for obtaining a work permit. As noted above, discrimination continues to be a major barrier for refugee claimants as they search for permanent housing.

\section{Toronto-Specific Programs}

Another theme identified throughout these interviews was the relevance of Toronto-specific programs for refugee claimants and how they affect their decision of where to look for housing. This is a new theme, as it was not discussed in the Preston study. This could be in part because the programs have been implemented after the Preston study was conducted. When service providers were asked if their clients are flexible in moving outside of Toronto, several respondents discussed that at first they seem to be open to the idea, but once they realize that certain funding programs will no longer be available to them, it is a far less appealing option. Refugee claimants appreciate the support programs available in Toronto and find comfort in knowing there are specific programs geared to them, whereas other cities may not offer the same supports. As Service Provider 3 states:

Furniture bank - two different applications, there is only one in the city of Toronto unfortunately, and if the person moves outside there is not much, so that is one thing that discourages clients from moving outside of Toronto because there are not as much services.

Programs that are only available in Toronto were described in further detail in Section 6.2 As discussed earlier, Housing Transition Funds and Housing Allowance programs are specific to Toronto residents and may indirectly encourage different groups like refugee claimants to stay in Toronto despite affordability challenges. These programs are very appealing to refugee claimants who are often looking for any additional funding they can receive to mitigate their vulnerable 
financial circumstances. Therefore, the absence of these programs in other cities in the GTHA presents a barrier for refugee claimants. Perhaps if these programs were also provided in other municipalities such as Mississauga or Caledon refugee claimants would be more inclined to move outside of Toronto. The nature of these programs makes the settlement process for refugee claimants easier, as the provide support through housing subsidies or furniture subsidies. While these programs only provide short-term or one-time assistance, they do so at a critical point in the lives of refugee claimants, making it more difficult for them to consider moving elsewhere.

In addition to the breadth of programs refugee claimants can apply for in Toronto, another motivating factor pushing them to stay in the city is their familiarity with their surrounding environment. This was captured by Service Provider 5 who stated:

You know, we always encourage our clients to look for housing outside of Toronto, is cheaper, and easier to find, and dealing with landlord is easier, but after a few months, Toronto becomes their comfort zone and they become familiar with transportation and everything else (including services), so they are really afraid to go somewhere else but we always encourage them.

This quote also brings to light the limitation of having most refugee-specific shelters located in Toronto. Often, refugee claimants do not want to be moved outside of Toronto because it has become such a familiar place for them. During their stays at these shelters, refugee claimants develop a sense of community through enrolling kids in local schools, establishing relationships with others at the shelter, shopping at nearby grocery stores, using the local transportation system, and interacting with businesses and residents in the area. These interactions are critical for claimants, as they occur within their first few months of arriving in a new city. These relationships and experiences become the only thing refugee claimants know upon arriving, which makes it increasingly difficult for them to consider moving to another city. Moving would mean that these refugee claimants would have to start from the beginning again, and most would prefer to avoid going through this tiring process one more time. Therefore, some are willing to go through more hurdles in order to stay in Toronto because it has become "home" for them over the past few months. Programs and funding specifically geared to refugee claimants continue to motivate them to remain in Toronto. 


\section{Systematic Gaps}

In addition to Toronto-specific programs, systematic gaps were identified as a major barrier to finding housing for refugee claimants. The specific types of systematic gaps that emerged will be unpacked and elaborated on below. Service providers stated that these gaps play a critical role and undermine the capability of refugee claimants to find permanent housing. This was captured in several ways by service providers as they expressed their frustration with current structuring of programs, facilitation between different cities, and eligibility requirements for certain programs that ease the financial burden on refugee claimants. For instance, Service Provider 5 stated:

We [Toronto] have a good program that makes housing easier for clients. It's the housing allowance, and the condition is that the client has to stay in the shelter for six months and after this point they get $\$ 500 / \$ 600$ [a month] as a housing allowance. These criteria are a big gap, because in doing this, they [the program] are encouraging the client to stay more. If the client finds housing in 3-4 months they tend to stay [in the shelter] because they want to receive the housing allowance, which makes sense because any human would want it.

While the Housing Allowance program's main objective is to lessen the housing hardships for vulnerable groups within the City of Toronto, the unintended consequence is that refugee claimants stay in shelters for six months just in order to qualify for the funding. In other words, some claimants might be staying at these shelters for longer durations, not just out of necessity but also to meet program eligibility requirements. This finding is concerning because the City of Toronto's homeless shelters reached capacity for several months due to a shortage of refugeespecific housing (City of Toronto, 2019a). Although it is not clear how many individuals/families are motivated by the Housing Allowance program to prolong their stay at the shelter, it may be having ripple effects as these units are not being made available to others who may be in higher need. In addition to gaps with current program structuring, service providers described the disjointed process refugee claimants are faced with when moving from one city to another. As Service Provider 1 states:

The system is not set up in a way to facilitate the movement of people, they are extremely vulnerable with no income between different cities...if they are receiving Ontario Works from the Toronto offices, it is extremely hard and takes so much time to actually open a 
file in Peel if you are moving to Mississauga or Brampton, there are so many hiccups in the way and facilitating.

This quote illuminates some obstacles highlighted under Toronto-Specific Programs, as they shed light on the difficulties refugee claimants face upon deciding to leave the shelter or move outside of Toronto. More broadly, this quote illustrates the challenges of coordination across programs targeted to refugee claimants. For instance, this coordination both between governments and within governments is fragmented and piecemeal, therefore hindering the ability for a smooth transition to another city. If such barriers were not present, it is likely that refugee claimants would be more likely to look outside of Toronto for housing. There are limitations and gaps in the existing system when it comes to facilitating the move of refugee claimants from one city to another and this puts claimants in a state of uncertainty where their funding is also cut off temporarily. Due to their vulnerable financial situations, the majority of claimants cannot afford to take this risk, and would rather stay in Toronto, despite the affordability and limited housing stock challenges. Furthermore, it was suggested that there are eligibility gaps for certain programs, as Service Provider 6 states: "One of the other challenges is that when we are applying for social assistance with them, we need a lease agreement. Both the landlord and assistance programs are asking for the information that the other requires."

This quote refers to eligibility gaps and mismatch with programs. For instance, in order for clients to qualify for specific housing transition funds, such as Last Month Rent, they need to show a copy of their unit's lease. However, this is an ineffective approach, as clients who are applying for housing transition funds need those same funds just to qualify for the apartment. Refugee claimants usually do not have enough to provide for first and last month rent, and therefore cannot secure a lease, which makes them ineligible for those funds. There is a clear discrepancy between the way programs have designed, their eligibility criteria, and the needs of refugee claimants.

Similarly, Service Provider 3 mentioned that when refugee claimants apply for units they have to submit first and last month rent as a money order in their application. This means that clients have to purchase a money order, which costs between $\$ 6-\$ 7$, and they do this for every application they submit. If a client submits 10 applications in one month, that is approximately 
$\$ 70$ that is being thrown out, and if their application is not approved, they pay another $\$ 6-\$ 7$ to convert each money order back into their account. While this may not seem like a large amount of money, it certainly exacerbates the financial constraints refugee claimants face.

There was a wide range of systematic gaps reported by different service providers, with varying degrees of impact. These programs, institutional, and procedural gaps need to be bridged to ensure refugee claimants can successfully integrate into the societies they seek refuge in.

As Toronto's housing market continues to favour those with higher incomes and more permanent immigration status it will become increasingly difficult for refugee claimants to find permanent housing. Barriers relating to affordability, employment, discrimination, systematic gaps and the absence of funding programs in other cities have all contributed to the hurdles refugee claimants face as they search for housing in Toronto. Relating back to Preston's study, which was completed almost a decade ago, it is evident that some barriers like affordability and discrimination continue to persist and challenge the efforts of service providers. Although new funding programs have been released since the Preston study was completed, such as the Housing Allowance and HSF, these were not able to resolve the affordability issues and conversely introduced unwanted behaviours. As such, refugee claimants have developed strategies to navigate around these barriers.

\subsubsection{Coping Mechanisms:}

This MRP was interested in gaining a better understanding of both the barriers refugee claimants face and the coping mechanisms they have developed. Despite all the barriers that were discussed in Section 6.3.1, refugee claimants have also displayed resilience in the face of several obstacles. Interviews with service providers revealed that refugee claimants are engaging in a few ways to mitigate their situation and circumventing the challenges they are facing in order to find permanent housing. Through my research, sharing accommodation and looking beyond the Greater Toronto Area (GTA) emerged as coping mechanisms, and therefore this MRP departs from Preston's study. 


\section{Sharing Accommodation}

The first coping mechanism theme that emerged was sharing accommodation with other refugee claimants. This seemed to be a growing trend, as claimants who are staying in the same shelter build strong relationships and consider sharing accommodation with the hope that they will find housing sooner. Sharing accommodation allows refugee claimants to share living costs with someone else, and because affordability was highlighted as the most critical barrier they face, this coping strategy has developed organically. This was captured by Service Provider 4, who discussed that:

Single mothers face extra barriers...so what these mothers do is find other mothers who have 1 or 2 children max, and once they are comfortable to move out, they will choose someone [another refugee] to make the situation easier for them.

Sharing accommodation seemed to be especially applicable for single mothers. In a few interviews, single mothers were described as having the most difficult experience in their search for permanent housing because, unlike other families where one parent worked and the other stayed home, single mothers often stay home or engage in part-time work if they have young children. While sharing accommodation is a great solution for some, refugee claimants need to be careful as this can make them ineligible for certain funding. Additionally, there are only some landlords that are willing to accept shared tenant households, so this is not a flawless system as the process for finding a landlord that is willing to do so may be challenging on its own. Thus, although sharing accommodation is a coping strategy, there are other issues associated with it.

\section{Looking Beyond the GTA}

Looking beyond the GTA was also seen a coping strategy to navigate around Toronto's complex rental market. While the suburbs and cities outside of the GTA have also experienced an increase in rental rates, the market is a bit cooler than Toronto's making it more within reach for refugee claimants (RBC, 2019). When service providers were asked how refugee claimants react to moving outside the city, they mentioned most are fearful and would rather stay in Toronto despite the affordability crisis. Refugee claimants are hesitant to move to other cities because they often develop and build a sense of community where they initially settled, and the absence of funding programs as mentioned in Section 6.0. 
Service providers explain to refugee claimants that Toronto's housing market is more expensive and getting a subsidized unit is extremely challenging as there are over 100,000 people on the waitlist, with an approximated 10-year timeframe. As such, they encourage clients to consider other cities with a cooler housing market, shorter subsidized housing waitlists, and those that will provide employment opportunities as well. They encourage clients to look towards cities that have better employment opportunities, as they understand having a job can significantly improve the lives of refugee claimants. Some clients welcome the option of moving outside the GTA in order to obtain subsidized housing because they understand getting a unit in Toronto is nearly impossible. As service provider 6 states:

We fill out applications for them in Toronto, more than a decade waiting time, huge waiting time unless their family members are huge and they go for townhouses, but we encourage them to apply for Durham, York and Peel region, some are going all the way to Hamilton to secure housing.

This quote reveals that service providers are directing their efforts towards helping clients complete applications for social housing in other cities that present more favourable opportunities than Toronto. Interviews further revealed that Sudbury was a favourable city because of their extremely short waitlist for subsidized housing. One of the organizations filled out a high volume of applications for subsidized housing in Sudbury and many of their clients relocated there. Similarly, another organization has begun to introduce this idea to their clients as early as possible, and before they establish themselves in Toronto with hopes that they will be more receptive to this change. This was captured by Service Provider 7 who said: "We just had a couple from Nigeria that moved to Sudbury, but we had this conversation with them as soon as they moved here so the timeline worked really well for them."

Service Provider 7 remarked on the importance of providing refugee claimants with other cities as options for settlement early on. Introducing them to this idea during their first few weeks of arrival is important, as they are less likely to have established relationships and developed a strong sense of community in the shelter. The idea of having to "restart" was highlighted as a significant factor that hinders refugee claimants' desires to move to another city. Therefore, 
doing this before they have established themselves, will prevent such feelings and increase the likelihood of them agreeing.

As Toronto continues to experience an affordability crisis, more people are likely to move outside of the city in their search for permanent housing. This particularly applies to refugee claimants and other demographic groups with low-income who do not have the financial capacity to remain in Toronto. Additionally, if current trends of refugee claimants entering Toronto continue to increase, the city's shelter system will become even more constrained and will not be able to respond to these growing needs. Although the City of Toronto Refugee Capacity Plan has recognized the need to provide more support for refugee claimants in finding transitional housing, this strategy is inefficient if refugee claimants cannot find permanent housing in the same city. It adds to the growing daily challenges refugee claimants experience, a more proactive approach is to inform these refugee claimants of their options to move to other cities outside the GTA for improved stability in their lives. Similarly, while sharing accommodation seems to be an effective approach for now, there are several other complications that can arise from this strategy. While these coping strategies are helping refugee claimants navigate the city's rental housing market for now, this area needs to be explored further to determine more concrete long-term strategies to improve their housing experiences. 


\subsection{Conclusion and Recommendations}

\subsection{Conclusion}

This paper has explored the challenges refugee claimants face and the coping strategies they have developed in their search for permanent housing in the city of Toronto. This research further analyzed these experiences in the context of Toronto's housing affordability crisis and compared them with findings from the Preston study. Research from this study revealed that the most significant barriers in finding permanent housing for refugee claimants were the housing market and affordability, employment, discrimination, Toronto-specific programs and systematic gaps. Affordability and discrimination were highlighted as barriers Preston's research and my research, which suggests that these issues continue to affect refugee claimants ten years later.

Although refugee claimants face numerous complex barriers in their search for permanent housing, the most notable barrier was the local housing market and affordability. This has been indicated by countless studies and the issue has growing implications, as the City of Toronto is going through an affordability crisis and this is affecting all residents (CANCEA and CUI, 2019). In addition to affordability challenges, refugee claimants face several forms of discrimination from landlords, their inability to obtain a work permit upon submitting a claim, Toronto-specific programs and systematic gaps have all added to their housing difficulties. In an effort to alleviate these barriers, refugee claimants were willing to share accommodation and move outside of the GTHA, however even these strategies proved to be flawed. The number of refugee claimants entering and settling in Toronto underscores the importance of improving their experiences, as finding adequate housing is an integral aspect of successfully integrating into society. 


\subsection{Recommendations:}

A series of recommendations to improve the experiences of refugee claimants as they search for permanent housing were developed through interviews with service providers.

Recommendations 1-3 were co-developed with interview participants, and recommendations 4-6 were developed by me through interview findings. The barriers and coping strategies used by refugee claimants in this MRP mirrored many of themes found in the Preston study, and as a result some of the recommendations closely align as well. This alludes to the fact that similar challenges that service providers were dealing with almost a decade ago, still persist.

\section{Recommendation \#1: Have at least one dedicated housing support worker at every refugee shelter.}

It was evident that having a dedicated housing support worker was a critical resource for refugee claimants. Of the three organizations that participated in the study, one had a dedicated housing worker while the other two discussed the need for it. Having someone at the shelter to explain their rights as a tenant, highlight housing challenges and provide one-on-one support to refugee claimants to address unique challenges is certainly needed. Service provider 7 mentioned that there are not any housing counsellors, but rather students or volunteers that will help refugee claimants in their search process. However, having someone with deep knowledge of the local housing market, and connections to other landlords/resources is critical for refugee claimants because of their limited knowledge and capacity to find adequate housing.

\section{Recommendation \#2: Streamline the process for obtaining a work permit}

The process of obtaining a work permit was highlighted as a significant barrier, therefore suggesting the importance of streamlining this process. The Immigration Refugee Board must review current structuring of application systems and get rid of the wait time for getting a work permit. Once refugee claimants have access to employment, they will be better positioned to achieve financial self-sufficiency. This reduction in work permit processing times can be achieved by hiring more staff or creating a new process to assess claims for work permits. 


\section{Recommendation \#3: Build refugee-specific subsidized housing}

Building and funding refugee specific housing would help to alleviate the many challenges claimants face. The current social housing waitlist system is not a practical path for refugee claimants to go through because of the extended waiting period. Providing refugee claimants with access to better housing will ease their integration process in the City, as they can devote more time to looking for meaningful employment. This recommendation would require more funding to implement and is more complex than some of the other ones, however, should still be considered.

\section{Recommendation \#4 Review and revise program eligibility requirements}

Building on the findings from the interviews, it was evident that eligibility requirements for certain programs motivate refugee claimants to extend their stay at shelters. This underscores the need for a comprehensive review of eligibility criteria for different programs to ensure that these programs are not exacerbating an issue - such as continued housing instability - in the process of trying to mitigate it. According to the interviewees, these inconsistencies were present across different municipal governments, such as the City of Mississauga and the City of Toronto.

\section{Recommendation \#5: Allow for a smoother facilitation between different cities}

Interviews revealed systematic gaps in relation to moving between different cities and the impact this has on the experiences of refugee claimants. The existing process for moving between different cities must be reviewed and improvements need to be made. For instance, if the current obstacles of transferring an Ontario Works case from one city to another were removed, there would be far fewer concerns about the hold on social assistance funds. If less complications emerge in this process, refugee claimants may be more inclined to move outside of Toronto as they will not face significant barriers or funding/service losses when trying to do so.

\section{Recommendation \#6: Create a system that will hold landlords accountable for their discriminatory behaviours}

Due to their immigration status, refugee claimants face several forms of discrimination from landlords, and their limited agency makes them defenseless. By creating a system where discriminatory comments/behaviours of landlords can be reported and logged, the occurrence of 
such comments may decrease. Creation of this system should incorporate a method by which landlords will be held accountable for their behaviours. This may deter future landlords from engaging in similar ways and reduce landlord discrimination towards refugee claimants. As discrimination was referred to as one of the most significant barriers, this recommendation would notably improve the housing trajectories of refugee claimants.

\subsection{Limitations and Future Research}

This study examined the experiences of refugee claimants searching for permanent housing from the perspectives of service providers during a time of housing affordability crisis. The scope of this MRP did not allow for survey questionnaires to be completed with refugee claimants, and therefore presents a limitation of the study. There is opportunity for future research to replicate this study and analyze the experiences of refugee claimants through speaking to them directly. Gathering data from refugee claimants directly is necessary in order to gain a more thorough understanding of the challenges they face and to compare against the Preston study. Additionally, this study provided a high-level analysis of Toronto's housing market, again presenting an opportunity for future research to provide an in-depth analysis of the city's housing market. Completing an in-depth analysis may allow for more direct connections to be drawn between housing trends in Toronto and the experiences of refugee claimants. 
APPENDICES 
Appendix A: Consent Form

\section{Consent to Participate in Research}

You are being invited to participate in a research study. Please read this consent form so that you understand what your participation will involve. Before you consent to participate, please ask any questions to be sure you understand what your participation will involve.

\section{Refugees and Permanent Housing in the City of Toronto}

\section{INVESTIGATORS}

This research is being conducted by Elaha Safi, a student of Ryerson's Master of Planning program. Magdalena Ugarte is the supervisor of this research and a professor at Ryerson University.

If you have any questions or concerns about the research, please feel free to contact me at 647524-4713.

\section{PURPOSE OF THE STUDY}

This study is designed to explore the experiences of staff that provide housing services to refugee claimants in the City of Toronto. In doing so, it will evaluate factors that have been identified in helping refugee claimants' transition to permanent housing. A total of 20 participants will be needed to take part in the semi-structured expert interviews. In order to participate you must be someone who works with refugees at COSTI Immigration Services, Romero House or Sojourn House, and currently assist or have assisted in refugees in obtaining permanent housing. Results of this study will contribute to a major research paper, which will be available at Ryerson University Library and Archives website once completed in late April 2020.

\section{WHAT YOU ARE BEING ASKED TO DO}

You are being asked to voluntarily take part in this one-on-one semi-structured interview that involves questions about your experiences as a service provider to refugee claimants. The interview is comprised of 5 broad questions relating to the strengths and challenges you see in finding permanent housing for refugee claimants, perspectives on what works effectively and what does not. Your responses will help the researcher identify if there are any variables/factors that are critical in finding permanent housing for refugee claimants.

\section{POTENTIAL BENEFITS}

There is no direct benefit to you for taking part in this study. It is hoped that this research will add qualitative depth to the Refugee Housing discussion and will ultimately provide recommendations for how the current approach can be improved through policy recommendations and service delivery. I cannot guarantee, however, that you will receive any benefits from participating in this study.

\section{WHAT ARE THE POTENTIAL RISKS TO YOU}

There are no potential risks to you. 


\section{YOUR IDENTITY WILL BE CONFIDENTIAL}

This interview is confidential and as such we will not be collecting information that will easily identify you, like your name or other unique characteristics. Anything discussed during this interview will be kept confidential, and interview results will be aggregated and summarized at a high level to ensure confidentiality is retained. The interview will be audio-recorded and later transcribed. General codes will be provided to each interviewee to ensure anonymity.

\section{HOW YOUR INFORMATION WILL BE PROTECTED AND STORED}

Aside from the interview responses no other information will be collected from you. To further protect your information, data stored by the researcher will be password protected and encrypted. Only the researchers named in this study will have access to the data as collected. Any future publications will include collective information (i.e., aggregate data). Your individual responses (i.e. raw data) will not be shared with anyone outside of the research team.

Any data collected will be kept until August $30^{\text {th }} 2020$, after which it will be destroyed. It will be kept until August 2020 because of the potential need to refer back to it when publishing the major research paper.

\section{INCENTIVE FOR PARTICIPATION}

There is no incentive for participating.

\section{YOUR RIGHTS AS A RESEARCH PARTICIPANT}

Participation in this research study is completely voluntary and you can withdraw your consent at any point. Please note that by taking part in the interview you are providing your consent for participation. By consenting to participate you are not waiving any of your legal rights as a research participant.

\section{QUESTIONS}

If you have any questions about this research, please feel free to ask now or at a later point in time. My contact information is:

ELAHA

elaha.safi@ryerson.ca

$647-524-4713$

If you have any questions about your rights or treatment as a research participant in this study, please contact the Ryerson University Research Ethics Board at rebchair@ryerson.ca (416) 9795042 . 
Hello [organization name],

My name is Elaha Safi. I am a graduate student at Ryerson University in the School of Urban and Regional Planning. I am contacting you to see if you might be interested in participating in a research study.

This research is being done as part of my Major Research Paper and my supervisor is Magdalena Ugarte, an assistant professor at Ryerson University. The focus of the research is to gain a deeper understanding of refugee's experience in obtaining permanent housing in the City of Toronto. In order to do this, it is critical to understand current challenges and success factors from the perspective of staff that work closely with refugee claimants.

To participate you need to be a service provider that provides refugee claimants with temporary accommodation and assists refugee claimants in finding permanent housing in any capacity. If you agree to volunteer, you will be asked to take part in a semi-structured interview comprised of 5 questions that can take between 20-45 minutes. Location and time of the interviews will be discussed at a later date to determine what's convenient for you.

The research is funded by the Canadian Excellence Research Chair and involves sharing of research findings to the funder. This research has been reviewed and approved by the Ryerson University Research Ethics Board.

If you are interested in more information about the study or would like to volunteer, please either call 647-524-4713 or let a staff member at the organization know. 
Appendix C: Interview Guide

\section{INTERVIEW GUIDE: EXPERT INTERVIEWS}

Introduce self and research project.

Obtain informed consent.

Answer any questions.

Thank you for taking the time to participate in this interview. Over the next 30 minutes or so, I would like to focus on five broad questions.

1. What types of housing settlement services does your organization provide to refugee claimants? What works well and what doesn't?

2. Have you noticed any trends in the types of challenges that refugee claimants face when searching for permanent housing?

3. What are some challenges you face as a service provider for this demographic?

4. Are there any factors that you have identified that help refugee claimants' transition to permanent housing?

5. Please describe any gaps in service provision that you have noticed through your work. What kind of changes would help your organization improve service provision (i.e. institutional, legal or funding)?

Thank you for answering the questions. Is there anything else you'd like to add before the interview ends?

Thank interviewee for their participation. 


\section{References}

Bergeron, J. and S. Potter (2006). "Family Members and Relatives: An Important Resource for Newcomers' Settlement?” Canadian Issues, Spring: 76-80.

Calvez, K.M. and E. Ilves (2008). Cultural Divide: A Neighbourhood Study of Immigrant Rental Housing in Vancouver. Vancouver: MOSAIC and Pivot Legal Society.

Canada Without Poverty (2020). The Right to Housing. http://www.cwp-csp.ca/poverty/ahuman-rights-violation/the-right-to-housing/

Carter, T. (2010). “The Challenges of Increasing Diversity in Areas of Urban Decline: A Winnipeg Case Study", Canadian Issues/Thèmes Canadiens (Newcomer's Experiences of Housing and Homelessness in Canada). Montréal: Association for Canadian Studies, Fall, 2010, pp. 96-99.

Carter, T. and J. Osborne (2009). "Housing and Neighbourhood Challenges of Refugee

Resettlement in Declining Inner-City Neighbourhoods: A Winnipeg Case Study”, Journal of Immigrant and Refugee Studies 7: 308-327.

Cubie, D. (2006). New Beginnings: Insights of Government-Assisted Refugees in BC into their Settlement Outcomes. Vancouver: Immigrant Settlement Services Society of BC.

Canada Mortgage and Housing Corporation (CMHC). (2010-2019). Rental Market Report: Toronto.

Canada Mortgage and Housing Corporation (CMHC). (2016) Housing Standards

Canada Mortgage and Housing Corporation (CMHC). (2018-2019). Secondary Rental Market Report: Toronto.

Canada Mortgage and Housing Corporation (CMHC). (2019). Understanding Core Housing Need. https://www.cmhc-schl.gc.ca/en/data-and-research/core-housing-need.

Canadian Centre for Economic Analysis and Canadian Urban Institute (2019). From Insight to Action: Toronto Housing Market Analysis.

City of Toronto. (2018). Council Issue Notes: Refugees. https://www.toronto.ca/citygovernment/council/2018-council-issue-notes/2018-refugees-issues-note/

City of Toronto. (2019a). Refugee Capacity Plan

City of Toronto. (2019b). Backgrounder: Refugees \& Asylum Claimants Experiencing Homelessness in the City of Toronto 
City of Toronto. (2019c). Issue Briefing: “Affordable Housing - Housing Affordability, Availability and Repair."

City of Toronto. (2020a). Daily Shelter Census. https://www.toronto.ca/city-government/dataresearch-maps/research-reports/housing-and-homelessness-research-and-reports/sheltercensus/

City of Toronto. (2020b). Toronto Progress Portal. https://www.toronto.ca/city-government/dataresearch-maps/toronto-progress-portal/

City of Toronto. (n.d.). Financial and Employment Support/ Subsidized Housing and Housing Benefits. https://www.toronto.ca/community-people/employment-social-support/housingsupport/subsidized-housing-housing-benefits/

City of Toronto. (n.d). Housing Stabilization Fund. https://www.toronto.ca/communitypeople/employment-social-support/support-for-people-in-financial-need/assistancethrough-ontario-works/policies-and-procedures/housing-stabilization-fund/

City of Toronto. (n.d). Employment \& Social Services: Assistance Through Ontario Works. https://www.toronto.ca/community-people/employment-social-support/support-forpeople-in-financial-need/assistance-through-ontario-works/

Community Legal Aid Ontario. (2019). Work Permits for Refugee Claimants. https://refugee.cleo.on.ca/en/work-permits-refugee-claimants

Crepeau, F. and Barutciski, M. (1994). Refugee rights in Canada and the 1951 Geneva convention. J. Refugee Study., (7), 239.

Febbraro, J. (2019). Toronto Storeys: Housing Affordability Is a Major Election Issue for Canadians. https://torontostoreys.com/canadian-housing-affordability/

Francis, J. (2010). "Poor Housing Outcomes Among African Refugees in Metro Vancouver", Canadian Issues/Thèmes Canadiens (Newcomer's Experiences of Housing and Homelessness in Canada). Montréal: Association for Canadian Studies, Fall, 2010, pp. 59-65.

Francis, J. (2009). "You Cannot Settle Like This": The Housing Situation of African Refugees in Metro Vancouver. Vancouver: Metropolis British Columbia, Working Paper Series, No. 09-02.

Government of Canada. (2019a). Claiming Asylum in Canada - What Happens? https://www.canada.ca/en/immigration-refugeescitizenship/news/2017/03/claiming_asylum_incanadawhathappens.html 
Government of Canada (2019b). Immigration Refugees and Citizenship. Ontario Resettlement Assistance Program. https://www.canada.ca/en/immigration-refugeescitizenship/corporate/publications-manuals/operational-bulletins-manuals/servicedelivery/resettlement-assistance-program.html

Government of Canada. (2019c). How Canada's Refugee System Works https://www.canada.ca/en/immigration-refugees-citizenship/services/refugees/canada-role.html

Government of Canada. (2020a). What is a Government-Assisted Refugee? https://www.cic.gc.ca/english/helpcentre/answer.asp?qnum=096\&top=11

Government of Canada. (2020b). Work Permit Processing Times https://www.canada.ca/en/immigration-refugees-citizenship/services/application/checkprocessing-times.html

Government of Canada. (2020c). Asylum Claims by Year. https://www.canada.ca/en/immigration-refugees-citizenship/services/refugees/asylumclaims.html

Government of Canada. (2020d). Canada Revenue Agency Child and Family Benefits. https://www.canada.ca/en/revenue-agency/services/child-family-benefits/canada-childbenefit-overview.html

Government of Canada (n.d). Glossary. https://www.canada.ca/en/services/immigrationcitizenship/helpcentre/glossary.html\#refugee claimant

Greenberg, T. and E. Martinez-Reyes (2010). Hidden: Newcomer Experiences of Homelessness at Fred Victor and the Learning Enrichment Foundation. Toronto: Learning Enrichment Foundation and Fred Victor

Hiebert, D. (2009b). "Newcomers in the Canadian Housing Market: A Longitudinal Study, 20012005", The Canadian Geographer 53 (3): 268-287.

Hiebert, D., D’Addario, S. and K. Sherrell (2009). "Taking Care of their Own? Or Falling Between the Cracks? Absolute and Relative Homelessness Among Immigrants, Refugees, and Refugee Claimants in Vancouver". Chapter 5.2 in Hulchanski, J.D. et al (editors). Finding Home: Policy Options for Addressing Homelessness in Canada. Toronto: Cities Centre, University of Toronto.

Hulchanski, J.D. (2003). What Factors Shape Canadian Housing Policy? The Intergovernmental Role in Canada's Housing System. Canadian Housing Policy: 2-30.

Kalinowski. T. (2020). Toronto Star: Construction of Rental Apartments at the Highest Level Since the 1970's. 
Lauer, S. R. and M. C. Yan (2007). Neighbourhood Houses and Bridging Social Ties. Metropolis British 81 Columbia: Working Paper Series 07-07.

Murdie, R. (2004). Housing Affordability: Immigrant and Refugee Experiences, in J.D. Hulchanski and M. Shapcott, eds. Finding Room: Options for a Canadian Rental Housing Strategy. Toronto: CUCS Press: 147-158.

Murdie, R. A. (2008). "Pathways to Housing: The Experiences of Sponsored Refugees and Refugee Claimants in Accessing Permanent Housing in Toronto.” Journal of International Migration and Integration 9(1): 81-101.

Murdie, R. (2010). "Precarious Beginnings: The Housing Situation of Canada's Refugees." Canadian Issues/Thèmes Canadiens (Newcomer's Experiences of Housing and Homelessness in Canada). Montréal: Association for Canadian Studies, Fall, 2010, pp. 47-53.

Muggah, R. and Abdenur, A. (2018). "Refugees and the City.” World Refugee Council Research Paper No.2. Centre for International Governance Innovation.

Ontario Human Rights Commission (OHRC). (2009). "Policy on Human Rights and Rental Housing."

Ontario Human Rights Commission (OHRC). (n.d). Housing as an International Human Right. http://www.ohrc.on.ca/en/human-rights-and-rental-housing-ontario-backgroundpaper/housing-international-human-right

Ontario. (1990). Human Rights Code

Ontario Long-Term Affordable Housing Strategy (2016).

Office of the Auditor General Annual Report. (2017). Ministry of Citizenship and Immigration. Settlement and Integration Services for Newcomers.

Preston, V., Murdie, R., D’Addario, S., Sibanda, P., Murnaghan A., Logan, J. and Ahn, M. (2011). "Precarious Housing and Hidden Homelessness Among Refugees, Asylum Seekers and Immigrants in the Toronto Metropolitan Area." The Ontario Metropolis Centre.

Royal Bank of Canada. (2019a). Big City Rental Blues: A Look at Canada's Rental Housing Deficit. http://www.rbc.com/economics/economic-reports/pdf/canadianhousing/housing_rental_sep2019.pdf

Royal Bank of Canada. (2019b). Housing Trends and Affordability. http://www.rbc.com/economics/economic-reports/pdf/canadian-housing/house$\underline{\text { mar2019.pdf }}$ 
Settlement.Org. (2019). I am a refugee claimant. Can I work?

https://settlement.org/ontario/immigration-citizenship/refugees/after-you-arrive/i-am-arefugee-claimant-can-i-work/

Smith, C. (2019). "Changing U.S. Policy and Safe Third Country Loophole Drive Irregular Migration to Canada". Migration Policy Institute.

Social Planning Toronto (2020). "The Good, the Bad, and the Ugly: Report Examines Which of Toronto's Problems are Better, and Which are Bigger, after 10 years of Austerity."

Sherrell, K. (2010). "Legal Status, Place, or Something Else? The Housing Experiences of Refugees in Winnipeg and Vancouver", Canadian Issues/Thèmes Canadiens (Newcomer's Experiences of Housing and Homelessness in Canada). Montréal: Association for Canadian Studies, Fall, 2010, pp. 52-59.

Shier, M. L., Graham, J. R., Fukuda, E., \& Turner, A. (2014). Predictors of Living in Precarious Housing Among Immigrants Accessing Housing Support Services. Journal of International Migration and Integration, 17(1), 173-192.

International Rescue Committee. (2018). "Urban Refuge: How Cities are Building Inclusive Communities."

United Nations High Commissioner for Refugees. (2010). Convention and Protocol Relating to the Status of Refugees.

Wayland, S. (2010). "Addressing the Housing Needs of Immigrants and Refugees in Canada", Canadian Issues/Thèmes Canadiens (Newcomer's Experiences of Housing and Homelessness in Canada). Montréal: Association for Canadian Studies, Fall, 2010, pp. 22-27. 